\title{
The Royal Image and Its Public
}

\author{
Suger, Saint-Denis, and the Promotion of a Monarchical Iconography in 12th- \\ Century France
}

\section{Elodie Leschot}

Identifying royal portraits is not an easy task. At the end of the 13th century, there was thus a habit of giving a name to every artwork representing a king. The oldest known satiric tale in the French language, the fabliau Des XXIII manières de vilains, mockingly relates an episode about a peasant who, upon his visit to Paris, attempts to identify the crowned figures in the gallery of kings on the façade of Notre-Dame de Paris:

The ugly baboon is the one who, when visiting Notre-Dame de Paris, looks at the statues of kings saying, "Look, there is Pepin, and look there is Charlemagne," and during this debate, his purse and the decoration of his hat are cut from behind. ${ }^{1}$

Debates surrounding the identification of the statues in the galleries of kings be it in Paris, Reims, Chartres, or Amiens - have lasted for centuries. Only after 1871, when the defeat of France by Prussia and the German states caused a period of crisis in French national thought and a subsequent flourishing of Catholic scholarship, was this approach called into question. ${ }^{2}$ Important

1 "Li vilains baboins est cil qui va devant Nostre-Dame a Paris et regarde les Rois et dit: 'Vez la Pepin, vez la Charlemainne'; et en demandtiers on li cope sa bource ou la corne de son chaperon par darriere." Paris, BnF, ms. fr. 1553, fol. 514v. This document is the oldest preserved version of the satiric narrative Des XXIII manieres de vilains, dated 1284.

2 The first to question this identification was: Adolphe Napoléon Didron, "Monographie de la cathédrale de Chartres. Description de la sculpture extérieure," Annales archéologiques 27 (1870), 18-31, esp. 26: "In these galleries of kings that one saw at Notre-Dame de Paris before the Revolution, and that one sees in Rheims, Amiens and Chartres, are not Kings of France, but Jewish Kings ... There are exceptions to what I am saying, but in very small numbers, and provided only by certain statues that one sees in Rheims, in the metropolis, an all-royal monument that must have been different from the others." See also the monograph:Johann Georg von Hohenzollern, Die Königsgalerie der französischen Kathedrale, Herkunft, Bedeutung, Nachfolge, (Munich, 1965). For the historiography of this period, see: Claude Digeon, La crise allemande de la pensée française 1870-1914 (Paris, 1959). 
epistemological, institutional, and political developments were transforming the relationship between the Church, the State, and French society; the field of research provided an area for expressing a strong reaction to these changes, as illustrated by the renewed interest in exegetical studies, the philological and literary analysis of biblical texts. Emile Mâle (1862-1954), a fervent supporter of the Catholic cause, was the first to consider in detail the iconography of the galleries of kings and, based on an analysis of the relationship between religious texts and images, to identify the sculptures as Old Testament figures. French researchers widely shared his hypothesis, while those in the Germanspeaking world questioned it. ${ }^{3}$ The two factions have since quarrelled on this issue, one identifying the statues as a genealogy of the kings of France and the other as a royal genealogy of Christ. ${ }^{4}$

Recently, Dany Sandron returned to this topic, showing that, already during the 13th century, a list of the kings of France appeared on one of the doors of the western façade of Notre-Dame de Paris. ${ }^{5}$ The clergy probably wrote this list, and the copy from the reign of Louis IX (r. 1226-1270) still exists in the Bibliothèque nationale de France in Paris. ${ }^{6}$ Based on the literary testimony of Des XXIII manières de vilains and the documentary evidence of this list, Sandron proceeded to identify the figures of the gallery once again as kings of France. Moreover, he proposed a direct involvement on the part of the French king in the conception of this ornamental programme.

The longstanding problem of the identity of the statues and the possibility of the king's involvement in their production are for us, however, secondary issues; irrespective of these concerns, the images were understood as portraits of Frankish monarchs by some 13th-century contemporaries. ${ }^{7}$ Indeed, the question of reception is crucial to the analysis of royal portraits, whose primary

3 Hohenzollern, Die Königsgalerie; Willibald Sauerländer, "Les statues royales du transept de Reims," Revue de l'Art 27 (1975), 9-30.

4 For these historiographical debates, see the summary in: Claudine Lautier, "Les deux galeries des rois de la cathédrale de Chartres," Bulletin monumental 169/1 (2011), 41-64, esp. 41-44.

5 Dany Sandron, "La cathédrale et les rois: Notre-Dame de Paris (XIIe-XIIIe siècles)," in Kirche als Baustelle: grosse Sakralbauten des Mittelalters, eds. Bruno Klein, Katja Schröck, and Stefan Bürger (Cologne, 2013), pp. 260-70, esp. 265.

6 Paris, BnF, ms. lat. 5921, fol. 47v. Benjamin Guérard, Cartulaire de l'église Notre-Dame de Paris (Paris, 1850), t. IV, p. 153 .

7 Marie-Thérèse Lorcin, "Des paysans retrouvés: les vilains du XIIIe siècle d'après quelques textes en langue d'oill," Cahiers d'histoire 45/2 (2000). Available at http://journals.openedition. org/ch/207?lang=en. Accessed 2020 Apr 3 . 
power lay in their impact on the viewer. ${ }^{8}$ The extent to which a royal portrait either resembled or idealized the depicted person was always secondary to its primary function, the "representation of power," according to Diane Bodart:

As an expression of sovereign majesty, the portrait is also its instrument, since it participates in the representation of power in the broadest sense, helping to determine the exercise of authority in action in the same way as royal insignia, while at the same time giving it a natural face. ${ }^{9}$

This is true not only of royal portraits from the Middle Ages but also more broadly; Bodart, for example, comes to this definition from her work on the functions of royal representations of the Spanish Habsburgs in the 16th and 17 th centuries.

In this essay, I intend to question the very origins of the galleries of kings in a period - the 12th century - when, properly speaking, the 'portrait' of the king did not exist. This period witnessed the triumphant appearance of the king's image in monumental art, as demonstrated by the profusion of sculptural figures of Old Testament kings and Merovingian and Carolingian sovereigns. These adorned the exteriors and interiors of the kingdom's most important churches, such as Saint-Remi de Reims, Saint-Germain-des-Prés, and above all Saint-Denis. ${ }^{10}$ Kings and queens were for the first time represented at SaintDenis as jamb figures on the Royal Portal (1135-1140) and, later, as jamb figures on the portal of the southern arm of the transept, the so-called Porte des Valois (115os). These two portals offer clues as to the origins, audiences, and functions of royal images in the medium of monumental sculpture.

To explore these dimensions, I will first analyse the iconographic formula of the jamb sculptures of the two portals of the abbey of Saint-Denis. I will

8 Antonio Pinelli, Gérard Sabatier, Barbara Stollberg-Rilinger, Christine Tauber, and Diane Bodart, "Le portrait du roi: entre art, histoire, anthropologie et sémiologie," Perspective 1 (2012), pp. 11-28.

$9 \quad$ Diane Bodart, Pouvoir du portrait sous les Habsbourg d'Espagne (Paris, 2011), p. 11. Bodart analyses the representational strategies and their origins and roles, including a consideration of dimensions, techniques, and materials.

For Saint-Remi of Reims, see:Anne Prache, Saint-Remi de Reims. L'oeuvre de Pierre de Celle et sa place dans l'architecture gothique (Genève, 1978). For Saint-Germain-des-Prés: Philippe Plagnieux, Le chevet de Saint-Germain-des-Prés et la définition de l'espace gothique au milieu du XIIe siècle (Paris, 1991); Philippe Plagnieux, "L'abbatiale de Saint-Germain-desPrés et les débuts de l'architecture gothique," Bulletin monumental 158 (2000), 7-85. For Saint-Denis, see the recent book (with complete bibliography): Saint-Denis: dans l'éternité des rois et reines de France, ed. Pascal Delannoy (Strasbourg, 2015). Also essential is: Atlas historique de Saint-Denis: des origines au XVIIIe siècle, ed. Michaël Wyss (Paris, 1996). 
then compare and contrast them with two other contemporary monuments displaying royal images: the Royal Portals at Notre-Dame-du-Fort in Étampes and at Chartres. This will allow for an understanding of the differences among the three cases and, moreover, of the basis for these discrepancies. Each of these institutional contexts had a different claim to the representation of royal figures; indeed, an iconography suitable for a royal abbey was not adequate for a collegiate church or a cathedral. ${ }^{11}$

\section{$1 \quad$ New Research Perspectives: The Portals at Saint-Denis, Étampes, and Chartres}

Of the 20 original jamb figures of the Royal Portal of Saint-Denis, 19 are known through the drawings of Bernard de Montfaucon and Benoist (figures. 10.1-3). ${ }^{12}$ The drawings show seven crowned figures from the north and central portals, five of which are represented with a crown and a sceptre (Figure. 10.1, nos. $3^{-}$ 5; Figure. 10.2, nos. 4-5). The remaining two, namely one female and one male figure from the central portal (Figure. 10.2, nos. 6-7), hold a scroll and a book respectively. These sculptures at Saint-Denis made explicit, for the first time, a relationship between the architectural structure and theological symbolism. ${ }^{13}$ Without returning to debates concerning the use of this iconographic formula for functionally integral figures on other buildings, we know that the jamb figures of the Royal Portal of Saint-Denis were indeed independent from their columns. ${ }^{14}$

The iconographic formula elaborated at Saint-Denis was immediately adopted for the Royal Portal of Étampes (Figure. 10.4) and, later, for the Royal Portal of Chartres (Figure. 10.5). $\cdot^{15}$ At Chartres, the iconographic formula has

11 Notre-Dame-du-Fort of Étampes was founded by Robert II the Pious (r. 996-1031) and was considered almost a second capital during the 12th century; meanwhile, Chartres was and is a famous Marian cathedral, governed by a powerful chapter.

12 Bernard de Montfaucon, Les monuments de la monarchie française, 5 vols (Paris, 1729-33), 1.

13 On the column that supports the upper structure of the portal, as the Old Testament supports the New Testament, see: Michèle Beaulieu, "Essai sur l'iconographie des statues-colonnes de quelques portails du premier art gothique," Bulletin Monumental 142/3 (1984), 273-307.

14 Eliane Vergnolle, "Gothic versus roman? La sculpture du deuxième quart du XIIe siècle," in Naissance de la sculpture gothique. Saint-Denis, Paris, Chartres, eds. Damien Berné, and Philippe Plagnieux (Paris, 2018), pp. 14-19, esp. 16.

15 On Notre-Dame of Étampes, see: Elise Baillieul, L'ancienne collègiale de Notre-Dame d'Etampes, un monument du premier art gothique (Lille, 2012). On Chartres: Whitney Snow Stoddard, The West Portals of Saint-Denis and Chartres (Cambridge, 1952); Whitney Snow Stoddard, Sculptors of the West Portals of Chartres Cathedral (New York 1987); Adolf 
been used only for some of the jamb sculptures. The vocabulary of the SaintDenis sculptures is visible on the left jamb of the north gate in the two male figures depicted with the crown and sceptre, attributed to the Master of Étampes (Figure. 10.6). ${ }^{16}$ Here, the final representation using this formula is the crowned female figure, without a sceptre, on the right jamb of the south gate (Figure. 10.7, no. 14).

All the other jamb figures of the Royal Portal of Chartres differ significantly from the model established at Saint-Denis in their attributes, their body shapes, and their hieratic poses (Figure. 10.8). Compared to the SaintDenis model, a nimbus has been added to and the sceptre removed from each figure, except for one, a crowned man on the right jamb of the south gate (Figure. 10.7, no. 13). In general, the treatment of the body and posture plays a fundamental role in the symbolism of the representations. The bodies of the figures of the Master of Étampes (Figure. 10.6), as well as those of the master who worked on the right jambs of the south gate, are marked by a rounded belly and a slim waist and hips; their postures are characterized by a downward tilt of the head, reminiscent of the Saint-Denis model (Figure. 10.2). However, the master sculptor responsible for the figures of the central portal disavowed this formula. ${ }^{17}$ There, the bodies are long and thin, without any roundness, as if joined to the column. Their gaze no longer seeks the spectator but fixes on something far away. This fusion of body and column, the hieratic pose, and the addition of the nimbus constitute the innovations of the jamb sculpture at Chartres, surrounding the figures with a sacred aura. ${ }^{18}$

These formal and iconographic changes influenced all later interpretations of the jamb figures. If the first modern French scholars in the 16th and 17th centuries still saw French sovereigns in the crowned jamb figures, Emile Mâle imposed a theological reading of these sculptures as Old Testament monarchs

Katzenellenbogen, The Sculptural Programs of Chartres Cathedral. Christ, Mary, Ecclesia (Baltimore, 1959); Philippe Plagnieux, "Le portail royal de Chartres. Une reformulation iconographique et stylistique," in Naissance de la sculpture gothique, eds. Berné et al., pp. 98-100.

16 Léon Pressouyre, "Précisions sur l'œuvre du 'Maître d'Étampes' au Portail royal de la cathédrale de Chartres," Bulletin de la Société nationale des antiquaires de France (1982), 96-97.

17 C. Edson Armi, The 'Headmaster' of Chartres and the Origins of 'Gothic' Sculpture (University Park, 1994).

18 Margot Fassler, "Liturgy and Sacred History in the Twelfth Century Tympana at Chartres," Art Bulletin 75 (1993), 449-520. 
and prophets announcing the New Law. ${ }^{19}$ This relied on an interpretation of the overall programme as a theological narration of the portals' upper part. ${ }^{20}$

The case of the Porte des Valois, on the south gate of the transept of SaintDenis, problematizes the general theological interpretation as well as the perceived role of Chartres as a model for art of the second half of the 12th century (Figure. 10.9). Scholars have long dated the portal to the 116os-1170s, but current researchers believe that it traces back to the early 115 os. $^{21}$ This earlier dating would mean that the realization of the Porte des Valois took place only a decade after that of the western portal of the abbey and just after that of Chartres. The attributes of these six figures are the same as those on the abbey's western portal: a sceptre, a crown, and a rotulus. Contrary to Chartres, the halo does not appear. One might deduce a lack of knowledge of the Chartres model. However, the existence of a crowned and haloed king from the Dionysian cloister, dating around 1145, goes against this hypothesis in its reliance on the figures of the Royal Portal at Chartres (Figure. 10.10)..$^{22}$ The presence of an iconographic

19 Jean Mabillon, Acta Sanctorum ordinis Sancti Benedicti (Vies des Saints de l'Ordre de saint Benoît), 9 vols (Paris, 1663-1702); Urbain Plancher, Histoire générale et particulière de Bourgogne, 4 vols (Dijon, 1739-1781); de Montfaucon, Les monuments de la monarchie française; Emile Mâle, L'art religieux du XIIe siècle en France. Étude sur les origines de l'iconographie du Moyen Âge (Paris, 1922). Emile Mâle follows the interpretation of: Jean Lebeuf, Recueil de divers écrits pour servir d'éclaircissements à l'histoire de France, et de supplément à la Notice des Gaules, 2 vols (Paris, 1738).

20 Mâle. L'art, chap. 5.; Paula L. Gerson, The west façade of Saint-Denis: an iconographic study (New York, 1970); Pamela Z. Blum, and Sumner McKnight Crosby, "Le portail central de la façade occidentale de Saint-Denis," Bulletin monumental 131 (1973), 209-66; Sumner Mcknight Crosby, The Royal abbey of Saint-Denis in the time of Abbot Suger (1122-1151) (New York, 1981); Pamela Z. Blum, "The Lateral Portals of the West Facade of the Abbey Church of Saint-Denis. Archaeological and Iconographical Considerations," in Abbot Suger and Saint-Denis: A Symposium, ed. Paula Lieber Gerson (New York, 1986), pp. 199228; Pamela Z. Blum, and Sumner McKnight Crosby, The Royal Abbey of Saint-Denis from Its Beginnings to the Death of Suger, 475-1151 (New Haven, 1987).

21 Pamela Z. Blum, "La Porte des Valois de Saint-Denis. À quelle époque son édification at-elle commencé?," Bulletin de la Société des fouilles archéologiques et des monuments historiques de l'Yonne 15 (1998), 21-25; Alain Erlande-Brandenburg, "La porte du cimetière à l'abbatiale de Saint-Denis dite 'Porte des Valois.' Emplacement originel, déplacement, datation," Comptes rendus des séances de l'Académie des inscriptions et belles-lettres (1999), 211-13.

22 Damien Berné, "Les statues-colonnes du cloître de Saint-Denis," in Naissance de la sculpture gothique, eds. Berné et al., pp. 202-05; Michaël Wyss, and Nicole Meyer-Rodrigues, "Nouvelles données archéologiques sur le cloître de l'abbaye de Saint-Denis," in Utilis est lapis in structura. Mélanges offerts à Léon Pressouyre, eds. Martine François, and PierreYves Le Pogam (Paris, 200o), pp. 111-26; Léon Pressouyre, "Did Suger Build the Cloister of Saint-Denis?," in Abbot Suger and Saint-Denis. A Symposium, ed. Paula Lieber Gerson (New York, 1986), pp. 229-44. 
formula from Chartres in the former cloister of Saint-Denis and its intermediate chronology between the western portal (1135-1140) and the Porte des Valois (115os) of Saint-Denis demonstrate the deliberate choice of the iconography associated with the jamb figures of the latter portal.

\section{High Society in Monumental Sculpture?}

Emile Mâle identified the figures from the Porte des Valois as Old Testament kings, six in the jambs and 30 others in the archivolts, by analogy with the western portal. ${ }^{23}$ Since then, only a few scholars have questioned his identification. ${ }^{24}$ Elisabeth Brown claims that the figures represent the reigning kings from the genealogical list of Mazarine Library MS 2013 who were known to have belonged to Saint-Denis. ${ }^{25}$ However, the number of kings on the list does not match the number on the portal. Brown passed over this inconsistency, explaining that Abbot Suger (1122-1151) and his monks must have thought that the kingdom had been ruled by about 30 kings. ${ }^{26}$ She also surmised that representing the exact number of kings would have assigned too much importance to certain kings who were unworthy because of their lack of support for Saint-Denis Abbey. Although some monarchs were indeed of secondary importance to the abbey of Saint-Denis, no primary sources allow for verification of her hypothesis.

However, I follow Brown's intuition that this is a programme with a historicizing dimension. Already present in illuminations, images of historical kings enter the field of monumental art during the 12th century. A prominent example of this is the Sainte-Anne portal at Notre-Dame of Paris, which can be dated to the mid-12th century (Figure. 10.11). ${ }^{27}$ In the middle of the tympanum

23 See: Erlande-Brandenburg, "La porte," p. 193.

24 Katzenellenbogen, The Sculptural Programs, pp. 27-36.

25 Bibliothèque Mazarine, ms. 2013, fols. 158v-175v; Elizabeth A. R. Brown, Saint-Denis, la basilique (Paris, 2001), pp. 140-43.

26 Brown, Saint-Denis, p. 142.

27 Willibald Sauerländer dated this portal to the tenure of Maurice de Sully, Bishop of Paris 116o-1196: Sauerländer, La Sculpture, pp. 18-22. Meanwhile, Jacques Thirion sees in it the work of his predecessor, Thibault, Bishop of Paris 1143-1158: Jacques Thirion, "Les plus anciennes sculptures de Notre-Dame de Paris," Comptes rendus des séances de l'Académie des inscriptions et belles-lettres (1970), 85-112. For a summary of dating assumptions, see also: Jacques Thirion, "Le portail Sainte-Anne à Notre-Dame de Paris," Cahiers de la Rotonde 22 (2000), 5-43. Thirion's dating was taken up by: Fabienne Joubert, "Le remploi de portails sculptés dans les monuments de la France gothique," Hortus artium medievalium 17 (2011), 201-08; Pierre-Yves Le Pogam, "Un art du recyclage: des sculptures gothiques remployées dans les façades gothiques," Cahiers archéologiques 56 (2016), 149-72. 
appears the Virgin and Child enthroned under a canopy and flanked by two angels holding censers. To the Virgin's right stands a bishop holding a phylactery, accompanied by a seated scribe. To her left is a kneeling king deploying a long document. Scholars have identified these figures as King Louis VII (r. 1137-1180) and Maurice de Sully, Bishop of Paris 116o-1196, or King Louis VI (r. 1108-1137) and Étienne de Garlande, a cleric active 1100-1147, in a symbolic scene showing the separation between secular and religious power. ${ }^{28}$ Jacques Thirion offered another interpretation, seeing in this iconography a representation of King Childebert I (r. 511-558) and Saint Germain, Bishop of Paris $555-576$, in a scene of donation showcasing the origins of the cathedral. ${ }^{29}$ Regardless, because of these attributes there was never any possibility of identifying this royal figure as a biblical king.

There was no lack of images of the historical monarchy in this period, as attested by the production of independent sculpture, like the six tomb effigies of Saint-Germain-des-Prés or the sculptures of enthroned emperors in the church in the church of Saint-Remi of Reims. ${ }^{30}$ The creation of such effigies served to highlight the respective religious institution's illustrious past and connection to the royal dynasty. A similar intent may explain the Porte des Valois at Saint-Denis. The history of the abbey's tutelary martyrs occupies the lintel, and on the voussoirs and the jambs are depicted the multitude of kings who have pledged allegiance to the holy protectors of the French monarchy.

In her recent study of the drapery of French early Gothic jamb sculptures, Janet E. Snyder supports this identification, which also runs counter

28 Emile Mâle, "Le portail de Sainte-Anne à Notre-Dame de Paris," Revue de l'art ancien et moderne 2 (1897), 231-46; Walter Cahn, "The Tympanum of the Portal of Saint-Anne at Notre-Dame de Paris and the iconography of the Division of Power in the Early Middle Ages," Journal of the Warburg and Courtauld Institue 32 (1969), 55-72; Anne LombardJourdan, "L'invention du roi fondateur à Paris au XIIe siècle: de l'obligation morale au thème sculptural," Bibliothèque de l'Ecole des chartes 155 (1997), 485-542; Thirion, "Le portail Sainte-Anne," pp. 5-43; Iliana Kasarska, "Les sculptures du XIIe siècle au portail Sainte-Anne à Notre-Dame de Paris," Bulletin monumental 159 (2001), 183-84, esp. 183.

29 Thirion, "Le portail Sainte-Anne," pp. 5-43.

30 On the tomb effigies at Saint-Germain-des-Prés, see: Philippe Plagnieux, "Autour du gisant de Childebert: les monuments funéraires des Mérovingiens à Saint-Germain-des-Prés et la politiques des abbés," in La figuration des morts dans la chrétienté médiévale jusqu'à la fin du premier quart du XIVe siècle, ed. Roger Grégoire (Fontevraud, 1989), pp. 183-94; Alain Erlande-Brandenburg, "Un gisant royal du milieu du XIIe siècle provenant de SaintGermain-des-Prés à Paris," Bulletin archéologique du Comité des Travaux Historiques et Scientifiques 15 (1979), 33-50. For the sculpture of emperors at Reims, see: Mario Kramp, Kirche, Kunst und Königsbild: zum Zusammenhang von Politik und Kirchenbau im capetingischen Frankreich des 12. Jahrhunderts am Beispiel der drei Abteien Saint-Denis, SaintGermain-des-Prés und Saint-Remi, Reims (Weimar, 1995), pp. 326-39. 
to the univocal theological interpretation. ${ }^{31}$ Through a meticulous analysis of material culture, she interprets the jamb figures as representing different social strata. Indeed, on the Royal Portal of Saint-Denis, only one of the seven crowned figures wears the regal dalmatic, the exclusive garment of royalty (Figure. 10.2, no. 5). ${ }^{32}$ The only crowned female figure is dressed in courtly attire (Figure. 10.2, no. 6).$^{33}$ Another figure stands out as a prince (Figure. 10.2, no. 4), and the other male figures can be identified as members of the elite of their time, as "remarkable leaders of their communities" (Figure. 10.1, nos. 1, 2, 6; Figure. 10.2, no. 7). ${ }^{34}$ Among the remaining 12 uncrowned figures, seven represent members of the elite (Figure. 10.1, nos. 1, 3, 6; Figure. 10.2, nos. 2-3; Figure. 10.3, nos. 4, 6), one is a Norman lady (Figure. 10.2, no. 1), two are court gentlemen (Figure. 10.3, nos. 2, 5), another one is a court gentleman but barefoot (Figure. 10.3, no. 3), and one is an associate of Christ (Figure. 10.1, no. 2). ${ }^{35}$ By an associate of Christ, Snyder refers to the clothes worn by this figure, which do not belong to the 12 th century. ${ }^{36}$ Apart from the 'associate,' whose interpretation is controversial, the images displayed the high nobility of the kingdom.

This cross-section of society was condensed on the Porte des Valois. Of the six jamb figures, the two at either end are dressed as chamberlains, while the four central figures are monarchs (Figure. 10.9). The choice to represent four sovereigns is unusual and finds no parallel on any other Gothic portal. ${ }^{37}$ In comparison, it is of particular interest that there is no monarch represented at either Étampes or Chartres. In Étampes, two court ladies, three lords or princes, and a chamberlain are shown. In Chartres, the composition includes only two lords (the work of the Master of Étampes), five court ladies, six dignitaries or chamberlains, and, for the first time, also four knights. These variations seem to be conscious choices on the part of the different religious institutions.

31 Janet E. Snyder, Early Gothic Column-Figure Sculpture in France. Appearance, Materials, and Significance (Farnham, 2011).

32 Snyder, Early, pp. 59-62.

33 Snyder, Early, pp. 37-39.

34 Snyder, Early, pp. 53-55.

35 Snyder, Early, pp. 77-80.

36 Snyder, Early, p. 78: "Other images associated by scholars with Old Testament personages appear in dress indistinguishable from clothing worn by the twelfth-century close associates of the monarch. In uniting the garb of ranking courtiers with sacred personages, the language of dress infers the significant integration of secular and sacred in 12th-century thought."

37 Janet E. Snyder's inventory of monarchical figures allows for identification of the portals on which only one king appears, namely at the cathedral of Saint-Maurice in Angers, the cathedral of Notre-Dame de Paris, the abbey of Saint-Germain-des-Prés, and the church of Notre-Dame in Vermenton. See: Snyder, Early, pp. 197-202. 


\section{Between Public and Private: The Royal Images on the Two Portals of Saint-Denis}

The contexts of the production and reception of the jamb sculptures differed strongly among Saint-Denis, Étampes, and Chartres, being tied to specific circumstances of each site. As for the figures on the western façade of SaintDenis, their identity as Old Testament characters and their place within the elaborated iconographic programme had to make sense to the specific social groups who saw the façade. To the intellectual elite, the two levels of the sculpted images on the Royal Portal - namely the literal (or historical) and the spiritual, the latter itself divided into the allegorical, the tropological (or moral), and the anagogical - would have been intelligible. ${ }^{38}$ If, thanks to their education, this audience had the interpretative tools to understand this programme, they might also have recognized, from their lived experiences, the different social statuses of the depicted figures. Did these members of the elite see the sculptures as a reflection of their current society or, alternatively, of a past society similar to theirs? Unfortunately, the lack of sources does not allow us to explore such nuances in the reception of these images. Regardless of the precise interpretation, the message of the programme is clear: society has always consisted of a hierarchy with a monarch at the top.

However, this educated class was not the only one with access to these images. It is possible to reconstruct the portal's original social environment thanks to Suger's account of the consecration of the western part of Saint-Denis:

First, the three bishops stood together in the middle of the new addition and blessed the water in the font placed there. They then went forth with the procession through the oratory of Saint Eustace and through the square called from ancient times "Pantera" because all things for buying and selling there are used goods. ${ }^{39}$

This source explains the function and age of the square in front of the church. Moreover, it confirms that, even before the reconstruction of the western façade by Abbot Suger, people who were not members of the nobility were

38 Henri de Lubac, Exégèse médiévale: les quatre sens de l'écriture, 3 vols (Paris, 1959-61).

39 Selected works of Abbot Suger of Saint-Denis, trans. with introduction and notes, Richard Cusimano, and Eric Whitmore (Washington, D.C., 2018), p. 43: "Qui in medio novi incrementi priorem inconsistenti dolio benedicentes aquam, per oratorium sancti Eustachii cum processione exeuntes per plateam que Panteria, eo quod inibi omnia emptioni et venditioni teruntur, antiquitus vocitatur, per aliam que in sacro cimiterio aperitur." 
present on a daily basis in this square. How would this public have perceived the new jamb sculptures on Suger's façade? As mentioned above, the jamb figures are clothed in the manner of members of the contemporary elite. An interaction is staged between these representations and the spectator, on the one hand, through their location on the lower reaches of the portal and, on the other, through their downward-tilted heads, as shown in Montfaucon's drawing of the figures of the central portal. Whether or not these viewers could precisely identify the various costumes and their social implications, they surely recognized the sculptures as depictions of nobles and kings, as attested by the Des XXIII manières de vilains. ${ }^{40}$

It is meaningful that the iconographic formula of the Royal Portal of SaintDenis was taken up immediately and almost without any change at Étampes. The town of Étampes had maintained close relations with the Capetian dynasty, and the city's collegiate church of Notre-Dame was a royal foundation. ${ }^{41}$ In his monograph on Notre-Dame d'Étampes, Jochen Staebel has argued that the building and its Royal Portal were commissions from Louis VII and his wife Eleanor of Aquitaine (r. 1137-1152). ${ }^{42}$ His analysis of the architectural and iconographic programme of the keystones and the south portal supports this hypothesis. According to Staebel, the south portal refers to the royal coronation, while the jamb sculptures represent contemporary sovereigns: Louis VI, Louis VII, Eleanor of Aquitaine, Queen Mother Adelaide (r. 1115-1137), Prince Henry (r. 1121-1175), and Henry, Archbishop of Sens 1122-1142. ${ }^{43}$ Nevertheless, this seductive interpretation does not stand up under Snyder's study of clothing, which demonstrates the absence of a monarch. In the case of Étampes, the absence of the monarch should not be interpreted as an intention to deny royal importance. Unlike Saint-Denis, Étampes was one of the capitals of Capetian power and a frequent place of residence for Louis VII. Since the king was often present in person, the need to represent him was secondary. ${ }^{44}$ Indeed, Staebel rightly identified this gate as the one used by the king; the presence of the monarch himself at the gate explains the absence of a sculpted figuration.

\footnotetext{
40 Paris, BnF, ms. fr. 1553 , fol. $514 v$.

41 Étampes had been a royal town since the construction of a fortified castle under Robert the Pious, and in 1124 the canons of Notre-Dame of Étampes were appointed chaplains of the king's castle, see: Atlas historique des villes de France; Île-de-France; Etampes; Essone, ed. Claudine Billot (Paris, 1989).

42 Staebel Jochen, Notre-Dame von Etampes: die Stiftskirche des 11.-13. Jahrhunderts unter besonderer Berücksichtigung ihrer frühgotischen Bauskulptur (Worms, 2003).

43 Staebel, Notre-Dame von Etampes, pp. 214-25.

44 Achille Luchaire, Histoire des institutions monarchiques sous les premiers Capétiens: $987-$ 1180. Etudes sur les actes de Louis VII (Paris, 1885), chap. 5.
} 
The fact that no monarch is represented on the Royal Portal of Chartres must be interpreted differently because of the historical and political context of this town, which was distinct from that of Saint-Denis and Étampes during the middle of the 12th century. Notre-Dame of Chartres was known as one of the centres of Marian worship in France. The cathedral was the seat of an important bishopric, led by famous figures such as Fulbert, Bishop of Chartres 1006-1028, who rebuilt the church in the 11th century, and Geoffroy de Lèves, Bishop of Chartres 1115-1149, active during the realization of the western façade. Less known but just as powerful, the cathedral chapter was essential in the organization and financing of building projects, which were referred to as the 'work of the church' (opus ecclesiae). ${ }^{45} \mathrm{~A}$ 12th-century obituary speaks to the canons' active participation in the decoration of the church through the commissioning of stained-glass windows, but no sources exist for the sculptural programme. ${ }^{46}$ The 39 canons who made up the chapter are documented in a charter of 1121-1124 by Geoffroy de Lèves, including 13 dignitaries. ${ }^{47}$ The vast majority of these canons came from the seigneurial or chivalric aristocracy. ${ }^{48}$ This may well explain the majority of dignitaries (six) and knights (four) on the Royal Portal.

Through the alteration of the figures' social identities and the addition of a halo to each figure, the Royal Portal of Chartres rejected the iconographic formula that had been established at Saint-Denis. This rejection could have conveyed a political message; it is more plausible, however, that it represented an adaptation of the formula to the local context of Chartres. Unlike Saint-Denis and Étampes, the Royal Portal of Chartres does not seem to refer to the royal network, and its jamb figures would have had a different viewership. Whereas monumental royal images were perfectly suitable for the façade of an abbey housing the regalia and the oriflamme (Saint-Denis) or that of a collegiate church whose religious community served as the chaplains of the royal palace (Étampes), they were certainly not suitable for a cathedral.

Even at Saint-Denis itself, the northern portal appears to have been geared towards an audience different not only from that of Chartres and Étampes but

45 André Chédeville, Chartres et ses campagnes (XIe-XIIIe s.) (Paris, 1973); Florian Mazel, "Pouvoirs locaux et acteurs du chantier," in Chartres. La grâce d'une cathédrale, ed. Michel Pansart (Strasbourg, 2013), pp. 41-56, esp. 47-48.

46 Eugène de Lépinois, and Lucien Victor Merlet, Cartulaire de Notre-Dame de Chartres d'après les cartulaires et les titres originaux, 3 vols (Chartres, 1861-65), pp. 111-12; Brigitte Kurmann-Schwarz, and Peter Kurmann, Chartres: la cathédrale (Saint-Léger-Vauban, 2001), pp. 149-50.

47 Mazel, "Pouvoirs locaux," p. 48, n. 97.

48 Mazel, "Pouvoirs locaux," p. 51. 
also that of the abbey's own western portal. This northern entrance, located at the height of the main altar, offered access to the cemetery (Figure. 10.12) ${ }^{49}$ In turn, on the northern side of the cemetery was a series of four churches: SaintMichel-du-Degré, Saint-Barthélémy, Saint-Pierre, and Saint-Paul, which were all under the monastery's jurisdiction. ${ }^{50}$ Another church, dedicated to Saint John the Baptist, was located in the cemetery itself but is yet to be found. ${ }^{51}$ Saint-Pierre Church functioned as a station during the processions of the rogations and feasts of Saint Mark and Saint Paul. ${ }^{52}$ At Saint-Denis, then, the portal of the transept's northern arm must, consequently, have serviced the processions on these occasions. Suger mentions this function twice: once in De Consecratione and again in De Administratione. ${ }^{53}$

Beyond this use for liturgical purposes and grand ceremonies, the portal was located on the side of the monastery that was connected to the kingdom's temporal power. Michael Wyss has uncovered the presence of a major Carolingian settlement west of Saint-Michel-du-Degré Church. ${ }^{54}$ This recalls the central role played by Saint-Denis in the quest for the legitimization of this same dynasty. ${ }^{55}$ A royal residence, probably constructed by Fardulfe, Abbot of Saint-Denis $797-806$, is attested for Charlemagne's stays. ${ }^{56}$ However, royal visits remained occasional, except under Charles the Bald, who spent every Easter at Saint-Denis. ${ }^{57}$ It was also during the latter's reign that the first fortifications of the monastery were built. ${ }^{58}$ The existence of a royal residence is still attested for the period of the Robertine dynasty $(888-987) .59$ This royal land

\footnotetext{
49 Wyss, Atlas, pp. 109-25.

$5^{\circ} \quad$ Wyss, Atlas, pp. 116-119.

$51 \quad$ Wyss, Atlas, p. 117.

52 Edward B. Foley, The first ordinary of the Royal Abbey of Saint-Denis in France: Paris, Bibliothèque Mazarine 526 (Fribourg, 1990), p. 247.

53 Suger, Ecrit sur la consécration de Saint-Denis; L'œuvre administrative; Histoire de Louis VII, trans. Françoise Gasparri (Paris, 1996), pp. 22-23, and 114-15. See also: ErlandeBrandenburg, "La porte," p. 212.
}

54 Michaël Wyss, "Un établissement carolingien mis au jour à proximité de l'abbaye de SaintDenis: la question du palais de Charlemagne," in “Aux marches du palais” Qu'est-ce qu'un palais médiéval?, ed. Annie Renoux (Le Mans, 2001), pp. 191-200.

It was thus within these walls that the second coronation of Pepin the Short took place in 754 and, successively, the anointing of his two sons by Pope Stephen II, who had just established his temporary residence at Saint-Denis (752-757).

56 Fardulfi abbatis carmina. MGH Poetae 1, ed. Ernst Dümmler (Hanover, 1881), p. 353.

57 Eugen Ewig, "Résidence et capitale pendant le haut Moyen Âge," Revue historique 230 (1963), 25-72, esp. 69.

$5^{8} \quad$ Annales Bertiniani, MGH SS, $r G_{13}$, ed. Georg Waitz (Hanover, 1883), p. 98.

59 Helgaud de Fleury, Vie de Robert le Pieux, trans. Robert-Henri Bautier, and Gillette Labory (Paris, 1965), Sources d'histoire médiévale 1, p. 96. 
north of the church was retained under the Capetian kings, as evidenced by the donation to the abbey of a residence (domus), including a house, a courtyard, a guest house and outbuildings, by Philip I (r. 106o-1108). ${ }^{60}$ Moreover, in 1140, Suger referred to a piece of the royal estate, on the church's northern side, intended for the maintenance of the lights of the new chapels of the western part. ${ }^{61}$ When, in the middle of the 12th century, the Capetian kings established their court in Paris, there was no longer a need for a royal palace in Saint-Denis; from this point on, there are no further testimonies to its existence. However, the northern portal's iconography, referring to the alliance between SaintDenis and royalty, may be a remaining indication of its function as a royal entrance to the church. ${ }^{62}$

The interior design of the church (Figure. 10.13) further supports this hypothesis. The entrance to the northern transept provided privileged access to the high altar and the altar of the holy martyrs. The eastern end of the church was accessible only to the clergy and the king, the latter accompanied by his court. ${ }^{63}$ If indeed the clergy entered the church via the south arm of the transept, which was connected to the abbey's cloister, where would the king and his court have entered? Although scholars have examined sources concerning royal entries into cities, nothing is known of royal entries into churches. ${ }^{64}$ The royal area to the north of the abbey, along with the interior layout of the church, suggests that the Porte des Valois was the one used by monarchs during royal ceremonies.

The iconography of the portal also refers to the frequent visits of the French king in times of war. Indeed, when the king went to the abbey to take the oriflamme - known in this period as the banner of Saint-Denis or of Vexin - he became the vassal of the saint and, by analogy, of the abbey. The kings' victories were linked to the intervention of their patron saint, as reported by Odo of Deuil in his crusade's account:

6o These donations are known thanks to the charter of renewal by Louis vi of the donation by his father of his house of Saint-Denis, See: Recueil des actes de Louis VI roi de France (1108-1137), ed. Jean Dufour, 2 vols, (Paris, 1992), n. 74, p. 167.

61 Suger, Oeuvres complètes, ed. Lecoy de la Marche (Paris, 1867), pp. 356-57.

62 It should be noted that this was not the entrance's only function, as demonstrated by its use in liturgical processions. See: Foley, The first ordinary, pp. $247^{-52}$.

63 Damien Berné, "Saint-Denis. L'espace et la mémoire du XIIe au début du XVIe siècle," Bulletin du centre d'études médiévales d'Auxerre 20/2 (2016). Available at http://journ als.openedition.org/cem/14568. Accessed 2020 Apr 30.

64 Les entrées royales françaises de 1328 à 1515, eds. Bernard Guenée, and François Lehoux (Paris, 1968); Joël Blanchard, "Les entrées royales; pouvoir et représentation du pouvoir à la fin du Moyen Age," Littérature 50 (1983), 3-14. 
While thus in the sight of everyone he requested from St- Denis the oriflamme and the permission to depart (a ceremony which was always the custom of our victorious kings), he aroused great lamentation and received the blessing of everyone's deepest affection. ... Meanwhile his mother and his wife and countless others went ahead to Saint-Denis. When the king arrived there presently, he found the pope and the abbot and monks of the church gathered together. Then he prostrated himself most humbly on the ground; he venerated his patron saint. The pope and the abbot opened the small golden door and drew out the silver reliquary a little way so that the king might be easily enabled to see and kiss the relic of him whom his soul venerated. Then, when the banner had been taken from above the altar after he had received the pilgrim's wallet and a blessing from the pope, he withdrew from the crowd to the monk's dormitory. The crowds and the king's wife and his mother, who nearly perished because of their tears and the heat, could not endure the delay; but to wish to depict the grief and wailing which occurred then is as foolish as it is impossible. ${ }^{65}$

This passage documents the royal presence at Saint-Denis. Louis viI's court and important ecclesiastical dignitaries gathered near the altar of the martyrs, in the chevet, awaiting the king's arrival. Then the king had to pray, asking for the banner and for permission to leave the kingdom. Thereafter, Louis VII

65 Odo of Deuil, De profectione Ludovici VII in orientem, trans. Virgina Gingerick Berry (New York, 1978), pp. 16-19: "Dum igitur a beato Dionysio vexillum, et abeundi licentiam petiit (qui mos semper victoriosis regibus fuit), visus ab omnibus planctum maximum excitavit, et intimi affectus omnium benedictionem accepit. Dum vero pergeret, rem fecit laudabilem, paucis tamen imitabilem, et forsitan suae celsitudinis nulli. Nam, cum prius religiosos quosque Parisiis visitasset, tandem foras progrediens, leprosorum adiit officinas. Ibi certe vidi eum cum solis duobus arbitris interesse, et per longam moram caeteram suorum multitudinem exclusisse. Interim mater ejus, et uxor, et innumeri alii ad Beatum Dionysium praecurrunt. Et ipse postmodum veniens, papam, et abbatem et Ecclesiae monachos invenit congregatos. Tunc ipse humillime humi prostratus, patronum suum adorat; Papa vero et abbas auream portulam reserant, et argenteam thecam paululum extrahunt, ut osculato rex et viso quem diligit anima sua, alacrior redderetur. Deinde sumpto vexillo desuper altari, et pera, et benedictione a summo pontifice, in dormitorium monachorum multitudini se subducit. Non enim patiebantur moras oppressio populorum, et mater et uxor, quae inter lacrymas et calorem pene spiritum exhalabant. Sed luctum et planctum qui ibi inerat velle describere, tam stultum est quam impossibile. Illo die retentis paucis suorum, in refectorio comedit cum fratribus; et os culatis postmodum omnibus recessit, orationibus et lacrymis omnium prosecutus." 
made direct contact with the relics of the patron saint. Once these components of the rite were completed, the king could take the banner.

Although this text presents the raising of the banner of Saint-Denis as an event deriving from a long tradition, the first mention of this ceremony in fact dates only to the reign of Louis VI. In 1124, Holy Roman Emperor Henry V (r. 1111-1125) threatened the Kingdom of France with an invasion. Suger recounts the event in his biography of King Louis:

When the plan was revealed to King Louis by his intimate friends, bravely and boldly he summoned a levy for which he did not wait, then he called up his nobles and explained to them the state of affairs. Since he recognized, both because he had often been told and had experienced it, that Saint-Denis was the special patron and after God the singular protector of the kingdom, he hastened to his church to implore him from the bottom of his heart, with prayers and gifts, that he would defend the kingdom, safeguard his person and repel the enemy in his usual manner. Then since the French have the privilege that, when their kingdom is invaded from without, they may place the saint's and defender's relics, with those of his companions, on the altar to defend them, this was done in the king's presence with solemnity and devotion. Then the king took from the altar the banner belonging to the county of the Vexin, which he held in fief of the church, following his vow received it as if from his lord. At the head of a handful of men to protect him, he flew off against the enemy, calling on the whole of France to follow him in strength. ${ }^{66}$

This account of the first raising of the banner by Louis VI emphasizes the king's vassalage to Saint-Denis as well as the role of the patron saint and his

66 Suger, Abbot of Saint Denis, The Deeds of Louis the Fat, trans. with introduction and notes, Richard Cusimano, and John Moorhead, (Washington, D.C., 1992), chap. 28: "Quod cum domino regi Ludovico intimorum relatione innotuisset, tam strenue, quam audacter delectum quem non exspectat cogit, nobiles asciscit, causam exponit. Et quoniam beatum Dionysium specialem patronum, et singularem post Deum regni protectorem, et multorum relatione et crebro cognoverat experimento, ad eum festinans, tam precibus quam beneficiis praecordialiter pulsat, ut regnum defendat, personam conservet, hostibus more solito resistat. Et quoniam hanc ab eo habent praerogativam, ut si regnum aliud regnum Francorum invadere audeat, ipse beatus et admirabilis defensor cum sociis suis, tanquam ad defendendum altari suo superponatur, eo praesente fit tam gloriose, quam devote. Rex autem vexillum ab altari suscipiens, quod de comitatu Vilcassini, quo ad Ecclesiam feodatus est, spectat, votive tanquam a Domino suo suscipiens, pauca manu contra hostes, ut sibi provideat, evolat, ut eum tota Francia sequatur potenter invitat." 
companions in protecting the kingdom. Odo's account of Louis VII, on the other hand, highlights the stages of the ceremony and the accompanying emotions. The discrepancy between the two accounts can be explained by the decade separating them, during which the royal claims to the abbey of SaintDenis became well established. Still, even during the reign of Louis VII, the ritual of the raising of the banner, and all the symbolic dimensions contained therein, was relatively new. The uniqueness of this ceremony to the abbey of Saint-Denis might explain the investment of Suger and his successors in promoting it. Moreover, Suger's reconstruction of the church may have been conceived to accommodate the relatively large number of people who attended this ceremony in the area of the altar of the martyrs, as suggested by Werner Jacobsen. ${ }^{67}$ This royal ceremony was essential for the abbey, which otherwise only hosted royal funerals; although the regalia had been housed at Saint-Denis since Louis VI, the coronation of the kings of France took place in the cathedral of Reims. ${ }^{68}$ Thus, the raising of the banner was the abbey church's most significant royal ceremony and an opportunity to present the abbey as essential to the monarchy. It would not be surprising to find on the Porte des Valois an iconography specially tailored to this ceremony. This would also explain the reuse of the portal in the new 13th-century transept, showing its importance for Suger's successors. ${ }^{69}$

\section{Conclusion}

Finally, let us return to the question of the royal portrait as it pertains to the sculptures at Saint-Denis, which represent a first step towards the kings' galleries of the 13th century. Because of their conditions of access, the two portals were not intended for the same audience. While the western façade was dedicated to the populace and the southern portal to the king and his court, they both hold an essential place in the history of the construction of royal power and, consequently, of French society.

67 Werner Jacobsen, "Liturgische Kollisionen im Kirchenraum: Sugers Neubau von SaintDenis. Voraussetzungen und Folgen," in Art, Cérémonial et Liturgie au Moyen Âge, eds. Nicolas Bock, Peter Kurmann, Serena Romano, and Jean-Michel Spieser (Rome, 2002), pp. 191-222, esp. 208-10.

68 Alain Erlande-Brandenburg, Le roi est mort. Etude sur les funérailles, les sépultures des rois de France jusqu'à la fin du XIIIe siècle (Paris, 1975), p. 86.

69 Joubert, "Le remploi," pp. 201-o8. 
The Capetian dynasty integrated biblical history, on the Royal Portal, considered the great history at this time and on the Porte des Valois, the Capetians were placed in succession to the Frankish monarchy. In the two monumental portals of the abbey church, there was a need to situate the Capetian dynasty historically and, thus, to legitimize it. Concerning the question of the legitimacy of the Capetians, Bernard Guenée has shown, through his analysis of textual sources, that the idea of Capetian pride emerged during the first two decades of the reign of Louis vir. ${ }^{70}$ This new vision of the dynasty would not have been possible had the Capetians not been legitimated by this time: previously, Hugh Capet's heirs had faced a severe disadvantage compared to the great counts and dukes of the realm because of their illegitimate blood. Guenée proposes that we understand this change, around the middle of the 12th century, as resulting from the power alliance that Louis VII established with the greatest lay lords of his kingdom. Moreover, he explains this change by the genealogical emphasis based on an Ottonian ancestry through female heritage. This last element was in fact never used by the Capetians to legitimize their dynasty; indeed, the strict rules that governed the writing of genealogy did not allow them to claim an illustrious past. Against this backdrop, the use of images was conducive to the production of a legitimizing discourse based on the historical continuity of royalty, as evident in the design of the two monumental portals of Saint-Denis Abbey. This representational strategy would continue well beyond the 12th century, following the example of the kings' galleries. Diane Bodart's above-quoted words now make full sense: ${ }^{71}$ these representations are an expression of sovereign majesty and, at the same time, an instrument for substantiating and legitimizing the exercise of royal power.

Indeed, though the portrait of the king had already existed before this time on seals and in illuminations, it was intended for a limited number of spectators, all of whom were elites. ${ }^{72}$ The use of a new broadcast medium, namely monumental sculpture, brought such images to a vast audience of ordinary people, thereby informing the daily experiences of an entire society. This catalysed an unprecedented change in the way the monarchy was perceived. I cannot confirm whether this was Suger's aim. However, if it was, then he succeeded, as

70 Bernard Guenée, "Les généalogies entre l'histoire et la politique. La fierté d'être Capétien, en France, au Moyen Âge," Annales 33 (1978), 450-77.

71 Pinelli et al., "Le portrait du roi," p. 11.

72 Anne-Orange Poilpré, "Le portrait royal en trône sous le règne de Charles le Chauve: l'espace contraint de la royauté," in L'image médiévale: fonction dans l'espace sacré et structuration de l'espace cultuel, eds. Cécile Voyer, and Eric Sparhubert (Turnhout 2011), pp. 325-39. 
evidenced by the spread of this visual formula throughout the entire kingdom as well as by the strengthening of royal power under Louis VII. ${ }^{73}$

\section{Bibliography}

\section{Primary Sources}

Annales Bertiniani, MGH SS, $r$ G 13, ed. Georg Waitz (Hanover, 1883).

de Lépinois, Eugène, and Merlet, Lucien Victor, Cartulaire de Notre-Dame de Chartres d'après les cartulaires et les titres originaux, 3 vols (Chartres, 1861-65).

Fardulfi abbatis carmina. MGH Poetae 1, ed. Ernst Dümmler (Hanover, 1881).

Guérard, Benjamin, Cartulaire de l'église Notre-Dame de Paris (Paris, 1850).

Helgaud de Fleury, Vie de Robert le Pieux, trans. Robert-Henri Bautier, and Gillette Labory (Paris, 1965), Sources d'histoire médiévale 1.

Odo of Deuil, De profectione Ludovici VII in orientem, trans. Virgina Gingerick Berry (New York, 1978).

Paris, BnF, ms. fr. 1553, fol. $514 \mathrm{v}$.

Recueil des actes de Louis VI roi de France (1108-1137), ed. Jean Dufour, 2 vols, (Paris, 1992). Selected works of Abbot Suger of Saint-Denis, trans. with introduction and notes, Richard Cusimano, and Eric Whitmore (Washington, D.C., 2018).

Suger, Ecrit sur la consécration de Saint-Denis; L'ouvre administrative; Histoire de Louis VII, trans. Françoise Gasparri (Paris, 1996).

Suger, Oeuvres complètes, ed. Lecoy de la Marche (Paris, 1867).

Suger, Abbot of Saint Denis, The Deeds of Louis the Fat, trans. with introduction and notes, Richard Cusimano, and John Moorhead, (Washington, D.C., 1992).

\section{Secondary Sources}

Armi, C. Edson, The 'Headmaster' of Chartres and the Origins of 'Gothic' Sculpture (University Park, 1994).

73 For the rehabilitation of the figure of Louis VII and his reign within the process of the construction of a state, see: Marcel Pacaut, Louis VII et les élections épiscopales (Paris, 1957); Marcel Pacaut, Louis VII et son royaume (Paris, 1964); Aryeh Graboïs, "Louis VII pèlerin," Revue d'histoire de l'Eglise de France 74/192 (1988), 5-22; Aryeh Graboïs, "Un mythe fondamental de l'histoire de France au Moyen Âge: le 'roi David,' précurseur du roi très chrétien," Revue historique 287 (1992), 11-31; Yves Sassier, Louis VII (Paris 1991); Yves Sassier, "La Corona regni: émergence d'une persona ficta dans la France du XIIe siècle," in La puissance royale. Image et pouvoir de l'Antiquité au Moyen Âge, eds. Emmanuelle Santinelli, and Christian-Georges Schwentzel (Rennes, 2012), pp. 99-110; Yves Sassier, Royauté et idéologie au Moyen-Âge. Bas-Empire, monde franc, France (IVe-XIIe siècle) (Paris, 2012), esp. chap. 5 . 
Atlas historique de Saint-Denis: des origines au XVIIIe siècle, ed. Michaël Wyss (Paris, 1996).

Atlas historique des villes de France; Île-de-France; Etampes; Essone, ed. Claudine Billot (Paris, 1989).

Baillieul, Elise, L'ancienne collègiale de Notre-Dame d'Etampes, un monument du premier art gothique (Lille, 2012).

Beaulieu, Michèle, "Essai sur l'iconographie des statues-colonnes de quelques portails du premier art gothique," Bulletin Monumental 142/3 (1984), 273-307.

Berné, Damien, "Saint-Denis. L'espace et la mémoire du XIIe au début du XVIe siècle," Bulletin du centre d'études médiévales d'Auxerre 20/2 (2016).

Berné, Damien, "Les statues-colonnes du cloître de Saint-Denis," in Naissance de la sculpture gothique. Saint-Denis, Paris, Chartres, eds. Damien Berné, and Philippe Plagnieux (Paris, 2018), pp. 202-05.

Blanchard, Joël, "Les entrées royales; pouvoir et représentation du pouvoir à la fin du Moyen Age," Littérature 50 (1983), 3-14.

Blum, Pamela Z., "The Lateral Portals of the West Facade of the Abbey Church of SaintDenis. Archaeological and Iconographical Considerations," in Abbot Suger and Saint-Denis: A Symposium, ed. Paula Lieber Gerson (New York, 1986), pp. 199-228.

Blum, Pamela Z., "La Porte des Valois de Saint-Denis. À quelle époque son édification a-t-elle commencé?," Bulletin de la Société des fouilles archéologiques et des monuments historiques de l'Yonne 15 (1998), 21-25.

Blum, Pamela Z., and McKnight Crosby, Sumner, "Le portail central de la façade occidentale de Saint-Denis," Bulletin monumental 131 (1973), 209-66.

Blum, Pamela Z., and McKnight Crosby, Sumner, The Royal Abbey of Saint-Denis from Its Beginnings to the Death of Suger, 475-1151 (New Haven, 1987).

Bodart, Diane, Pouvoir du portrait sous les Habsbourg d'Espagne (Paris, 2011).

Brown, Elizabeth A. R., Saint-Denis, la basilique (Paris, 2001).

Cahn, Walter, "The Tympanum of the Portal of Saint-Anne at Notre-Dame de Paris and the iconography of the Division of Power in the Early Middle Ages," Journal of the Warburg and Courtauld Institue 32 (1969), 55-72.

Chédeville, André, Chartres et ses campagnes (XIe-XIIIe s.) (Paris, 1973).

de Lubac, Henri, Exégèse médiévale: les quatre sens de l'écriture, 3 vols (Paris, 1959-61).

de Montfaucon, Bernard, Les monuments de la monarchie française, 5 vols (Paris, 1729-33).

Didron, Adolphe Napoléon, "Monographie de la cathédrale de Chartres. Description de la sculpture extérieure," Annales archéologiques 27 (1870), 18-31.

Digeon, Claude, La crise allemande de la pensée française 1870-1914 (Paris, 1959).

Erlande-Brandenburg, Alain, Le roi est mort. Etude sur les funérailles, les sépultures des rois de France jusqu'à la fin du XIIIe siècle (Paris, 1975). 
Erlande-Brandenburg, Alain, "Un gisant royal du milieu du XIIe siècle provenant de Saint-Germain-des-Prés à Paris," Bulletin archéologique du Comité des Travaux Historiques et Scientifiques 15 (1979), 33-50.

Erlande-Brandenburg, Alain, "La porte du cimetière à l'abbatiale de Saint-Denis dite 'Porte des Valois.' Emplacement originel, déplacement, datation," Comptes rendus des séances de l'Académie des inscriptions et belles-lettres (1999), 211-13.

Ewig, Eugen, "Résidence et capitale pendant le haut Moyen Âge," Revue historique 230 (1963), 25-72.

Fassler, Margot, "Liturgy and Sacred History in the Twelfth Century Tympana at Chartres," Art Bulletin 75 (1993), 449-520.

Foley, Edward B., The first ordinary of the Royal Abbey of Saint-Denis in France: Paris, Bibliothèque Mazarine 526 (Fribourg, 1990).

Gerson, Paula L., The west façade of Saint-Denis: an iconographic study (New York, 1970). Graboïs, Aryeh, “Louis VII pèlerin," Revue d'histoire de l'Eglise de France 74/192 (1988), $5^{-22 .}$

Graboïs, Aryeh, "Un mythe fondamental de l'histoire de France au Moyen Âge: le 'roi David,' précurseur du roi très chrétien," Revue historique 287 (1992), 11-31.

Guenée, Bernard, "Les généalogies entre l'histoire et la politique. La fierté d'être Capétien, en France, au Moyen Âge," Annales 33 (1978), 450-77.

Jacobsen, Werner, "Liturgische Kollisionen im Kirchenraum: Sugers Neubau von SaintDenis. Voraussetzungen und Folgen," in Art, Cérémonial et Liturgie au Moyen Âge, eds. Nicolas Bock, Peter Kurmann, Serena Romano, and Jean-Michel Spieser (Rome, 2002), pp. 191-222.

Jochen, Staebel, Notre-Dame von Etampes: die Stiftskirche des 11.-13. Jahrhunderts unter besonderer Berücksichtigung ihrer frühgotischen Bauskulptur (Worms, 2003).

Joubert, Fabienne, "Le remploi de portails sculptés dans les monuments de la France gothique," Hortus artium medievalium 17 (2011), 201-08.

Kasarska, Iliana, "Les sculptures du XIIe siècle au portail Sainte-Anne à Notre-Dame de Paris," Bulletin monumental 159 (2001), 183-84.

Katzenellenbogen, Adolf, The Sculptural Programs of Chartres Cathedral. Christ, Mary, Ecclesia (Baltimore, 1959).

Kramp, Mario, Kirche, Kunst und Königsbild: zum Zusammenhang von Politik und Kirchenbau im capetingischen Frankreich des 12. Jahrhunderts am Beispiel der drei Abteien Saint-Denis, Saint-Germain-des-Prés und Saint-Remi, Reims (Weimar, 1995).

Kurmann-Schwarz, Brigitte, and Kurmann, Peter, Chartres: la cathédrale (Saint-LégerVauban, 2001).

Lautier, Claudine, "Les deux galeries des rois de la cathédrale de Chartres," Bulletin monumental 169/1 (2011), 41-64. 
Lebeuf, Jean, Recueil de divers écrits pour servir d'éclaircissements à l'histoire de France, et de supplément à la Notice des Gaules, 2 vols (Paris, 1738).

Le Pogam, Pierre-Yves, "Un art du recyclage: des sculptures gothiques remployées dans les façades gothiques," Cahiers archéologiques 56 (2016), 149-72.

Les entrées royales françaises de 1328 à 1515, eds. Bernard Guenée, and François Lehoux (Paris, 1968).

Lombard-Jourdan, Anne, "L'invention du roi fondateur à Paris au XIIe siècle: de l'obligation morale au thème sculptural," Bibliothèque de l'Ecole des chartes 155 (1997), $485-542$.

Lorcin, Marie-Thérèse, "Des paysans retrouvés: les vilains du XIIIe siècle d'après quelques textes en langue d'oïl," Cahiers d'histoire 45/2 (2000).

Luchaire, Achille, Histoire des institutions monarchiques sous les premiers Capétiens:9871180. Etudes sur les actes de Louis VII (Paris, 1885).

Mabillon, Jean, Acta Sanctorum ordinis Sancti Benedicti (Vies des Saints de l'Ordre de saint Benoît), 9 vols (Paris, 1663-1702).

Mâle, Emile, "Le portail de Sainte-Anne à Notre-Dame de Paris," Revue de l'art ancien et moderne 2 (1897), 231-46.

Mâle, Emile, L'art religieux du XIIe siècle en France. Étude sur les origines de l'iconographie du Moyen Âge (Paris, 1922).

Mazel, Florian, "Pouvoirs locaux et acteurs du chantier," in Chartres. La grâce d'une cathédrale, ed. Michel Pansart (Strasbourg, 2013), pp. 41-56.

Mcknight Crosby, Sumner, The Royal abbey of Saint-Denis in the time of Abbot Suger (1122-1151) (New York, 1981).

Pacaut, Marcel, Louis VII et les élections épiscopales (Paris, 1957).

Pacaut, Marcel, Louis VII et son royaume (Paris, 1964).

Pinelli, Antonio, Sabatier, Gérard, Stollberg-Rilinger, Barbara, Tauber, Christine, and Bodart, Diane, "Le portrait du roi: entre art, histoire, anthropologie et sémiologie," Perspective 1 (2012), pp. 11-28.

Plagnieux, Philippe, "Autour du gisant de Childebert: les monuments funéraires des Mérovingiens à Saint-Germain-des-Prés et la politiques des abbés," in La figuration des morts dans la chrétienté médiévale jusqu'à la fin du premier quart du XIVe siècle, ed. Roger Grégoire (Fontevraud, 1989), pp. 183-94.

Plagnieux, Philippe, Le chevet de Saint-Germain-des-Prés et la définition de l'espace gothique au milieu du XIIe siècle (Paris, 1991).

Plagnieux, Philippe, "L'abbatiale de Saint-Germain-des-Prés et les débuts de l'architecture gothique," Bulletin monumental 158 (2000), 7-85.

Plagnieux, Philippe, "Le portail royal de Chartres. Une reformulation iconographique et stylistique," in Naissance de la sculpture gothique. Saint-Denis, Paris, Chartres, eds. Damien Berné, and Philippe Plagnieux (Paris, 2018), pp. 98-10o.

Plancher, Urbain, Histoire générale et particulière de Bourgogne, 4 vols (Dijon, 1739-1781). 
Poilpré, Anne-Orange, "Le portrait royal en trône sous le règne de Charles le Chauve:l'espace contraint de la royauté," in L'image médiévale: fonction dans l'espace sacré et structuration de l'espace cultuel, eds. Cécile Voyer, and Eric Sparhubert (Turnhout 2011), pp. 325-39.

Prache, Anne, Saint-Remi de Reims. L'ouvre de Pierre de Celle et sa place dans l'architecture gothique (Genève, 1978).

Pressouyre, Léon, "Précisions sur l'œuvre du 'Maître d'Étampes' au Portail royal de la cathédrale de Chartres," Bulletin de la Société nationale des antiquaires de France (1982), 96-97.

Pressouyre, Léon, "Did Suger Build the Cloister of Saint-Denis?," in Abbot Suger and Saint-Denis. A Symposium, ed. Paula Lieber Gerson (New York, 1986), pp. 229-44.

Saint-Denis: dans l'éternité des rois et reines de France, ed. Pascal Delannoy (Strasbourg, 2015).

Sandron, Dany, "La cathédrale et les rois: Notre-Dame de Paris (XIIe-XIIIe siècles)," in Kirche als Baustelle: grosse Sakralbauten des Mittelalters, eds. Bruno Klein, Katja Schröck, and Stefan Bürger (Cologne, 2013), pp. 26o-70.

Sassier, Yves, Louis VII (Paris 1991).

Sassier, Yves, "La Corona regni: émergence d'une persona ficta dans la France du XIIe siècle," in La puissance royale. Image et pouvoir de l'Antiquité au Moyen Âge, eds. Emmanuelle Santinelli, and Christian-Georges Schwentzel (Rennes, 2012), pp. 99-110.

Sassier, Yves, Royauté et idéologie au Moyen-Âge. Bas-Empire, monde franc, France (IV ${ }_{-}$ XIIe siècle) (Paris, 2012).

Sauerländer, Willibald, "Les statues royales du transept de Reims," Revue de l'Art 27 (1975), 9-30.

Snyder, Janet E., Early Gothic Column-Figure Sculpture in France. Appearance, Materials, and Significance (Farnham, 2011).

Stoddard, Whitney Snow, The West Portals of Saint-Denis and Chartres (Cambridge, 1952).

Stoddard, Whitney Snow, Sculptors of the West Portals of Chartres Cathedral (New York 1987).

Thirion, Jacques, "Les plus anciennes sculptures de Notre-Dame de Paris," Comptes rendus des séances de l'Académie des inscriptions et belles-lettres (1970), 85-112.

Thirion, Jacques, "Le portail Sainte-Anne à Notre-Dame de Paris," Cahiers de la Rotonde 22 (2000), 5-43.

Vergnolle, Eliane, "Gothic versus roman? La sculpture du deuxième quart du XIIe siècle," in Naissance de la sculpture gothique. Saint-Denis, Paris, Chartres, eds. Damien Berné, and Philippe Plagnieux (Paris, 2018), pp. 14-19.

von Hohenzollern, Johann Georg, Die Königsgalerie der französischen Kathedrale, Herkunft, Bedeutung, Nachfolge, (Munich, 1965). 
Wyss, Michaël, and Meyer-Rodrigues, Nicole, "Nouvelles données archéologiques sur le cloître de l'abbaye de Saint-Denis," in Utilis est lapis in structura. Mélanges offerts à Léon Pressouyre, eds. Martine François, and Pierre-Yves Le Pogam (Paris, 200o), pp. $111-26$.

Wyss, Michaël, "Un établissement carolingien mis au jour à proximité de l'abbaye de Saint-Denis: la question du palais de Charlemagne," in "Aux marches du palais" Qu'est-ce qu'un palais médiéval?, ed. Annie Renoux (Le Mans, 2001), pp. 191-20o. 


\section{Illustrations}

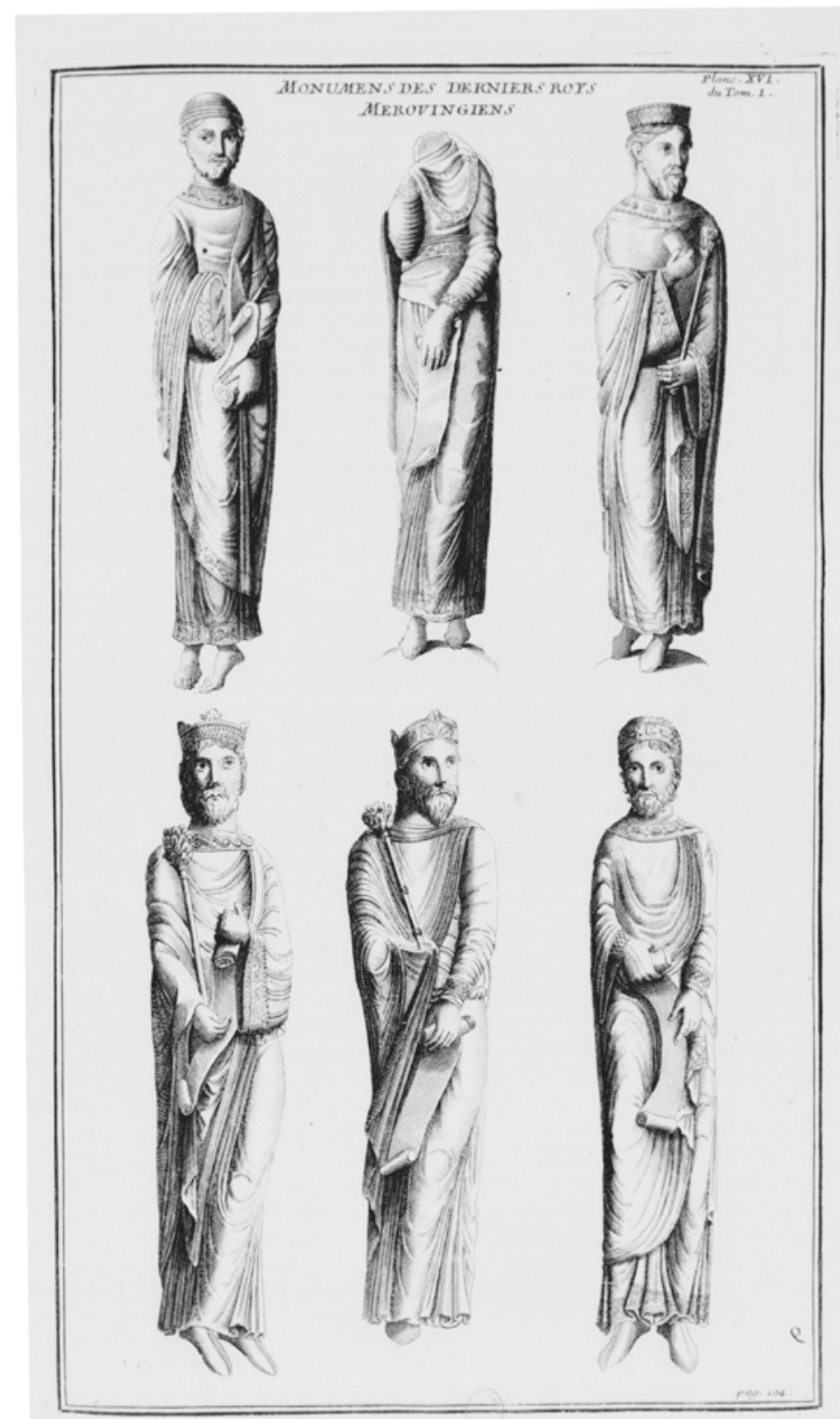

FIGURE 10.1 Bernard de Montfaucon, Column-figures of the Royal Portal of Saint-Denis, north gate (c. 1135-1140), in Les monuments de la monarchie française, t. I, (Paris, 1729), planches XVI (numbered from top left in reading direction: 1.1, 1.2, 1.3, 1.4, 1.5 and 1.6) (c): BNF 


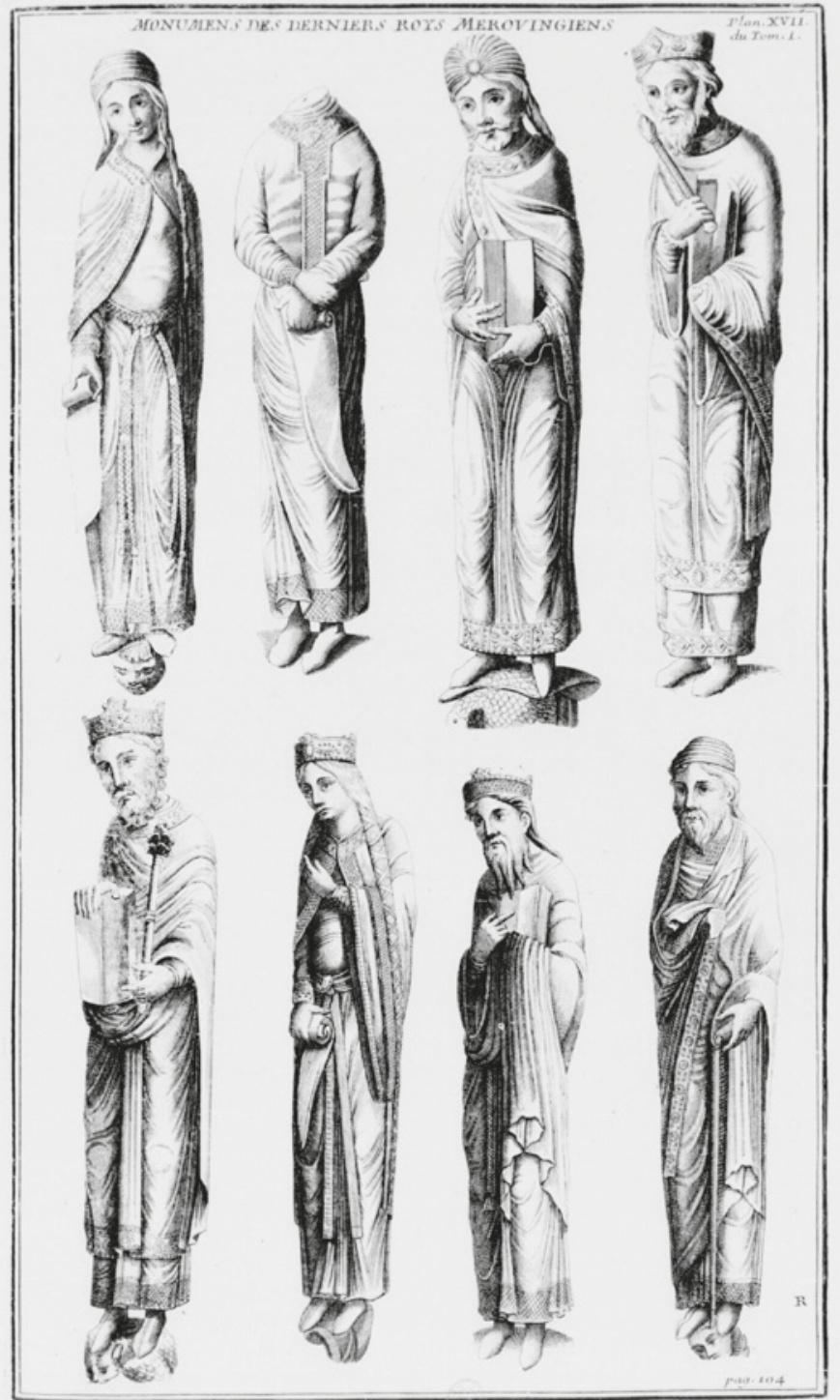

FIGURE 10.2 Bernard de Montfaucon, Column-figures of the Royal Portal of Saint-Denis, center gate (c. 1135-1140), in Les monuments de la monarchie française, t. I, (Paris, 1729), planches XVII, (numbered from top left in reading direction: 2.1, 2.2. 2.3, 2.4, 2.5, 2.6, 2.7 and 2.8 ,

(c): $\mathrm{BNF}$ 


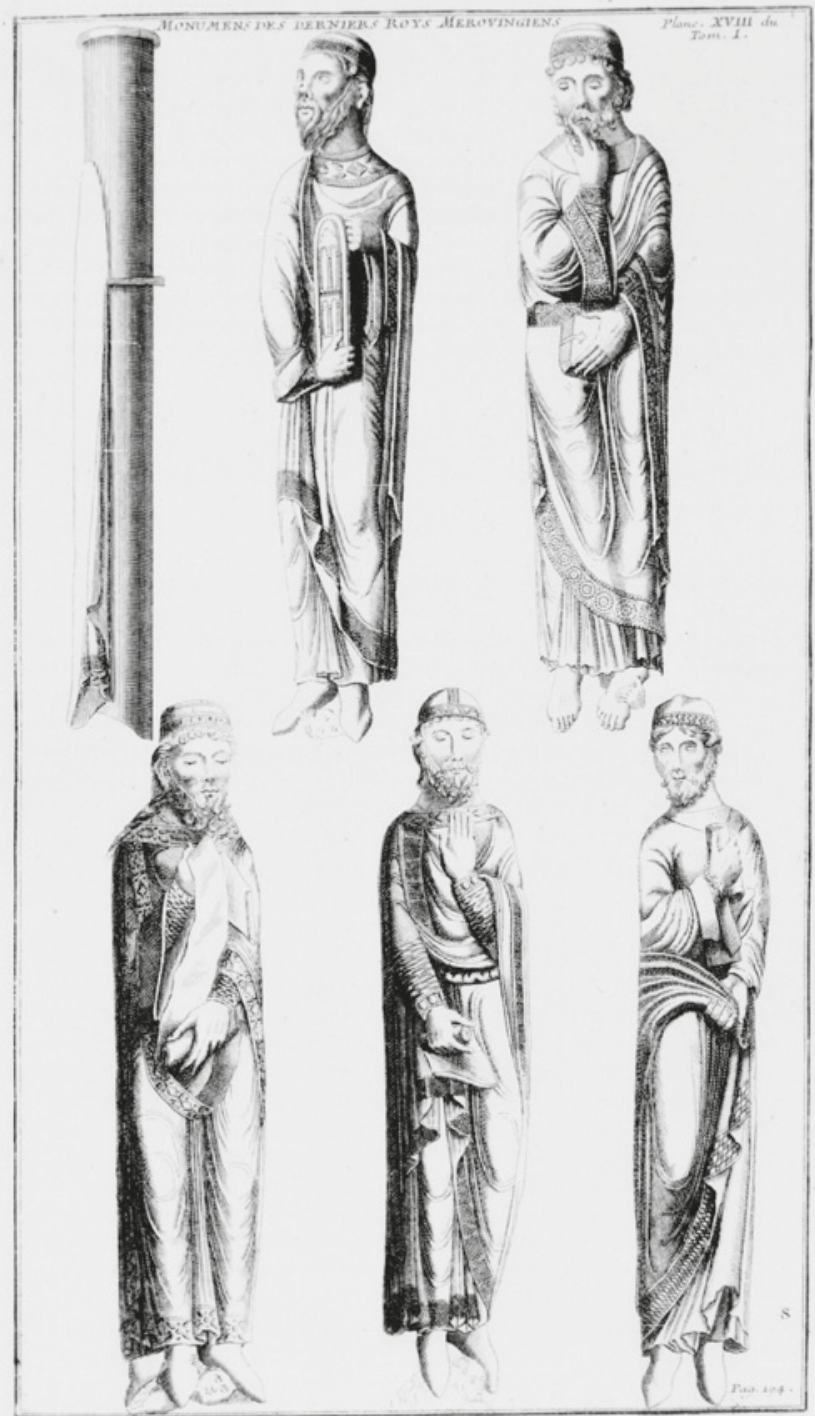

FIGURE 10.3 Bernard de Montfaucon, Column-figures of the Royal Portal of Saint-Denis, south gate (c. 1135-1140), in Les monuments de la monarchie française, t. I, (Paris, 1729), planches XVII (numbered from top left in reading direction: 3.1, 3.2, 3.3, 3.4, 3.5, and 3.6) (c): $\mathrm{BNF}$ 


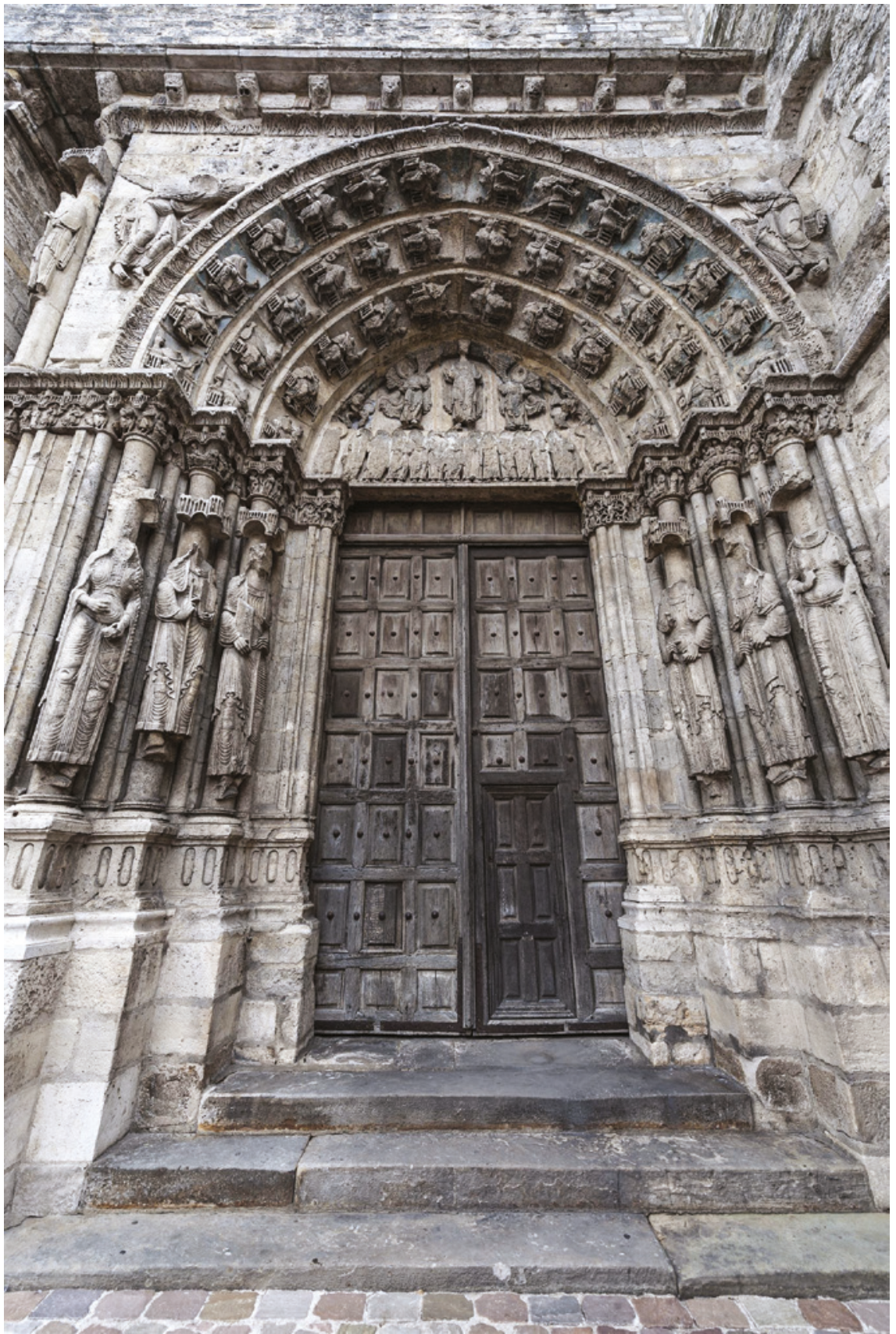

FIGURE 10.4 Etampes, Notre-Dame, Royal Portal, south gate, c. 1140, (numbered from left to right: 4.1, 4.2, 4.3, 4.4, 4.5, and 4.6)

(c) CLAUDIO GIOVANNI COLOMBO 


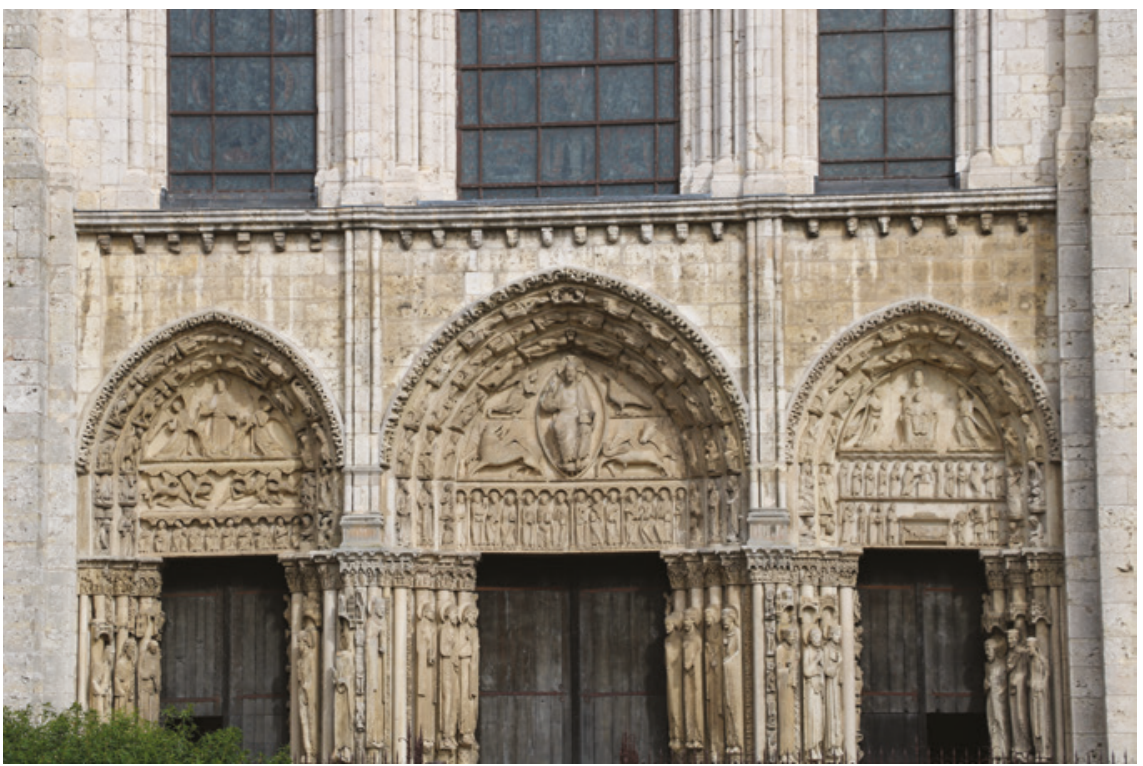

FIG URE 10.5 Chartres, Notre-Dame, Royal Portal, western façade, c. 1145-1155 (C) AUTHOR 


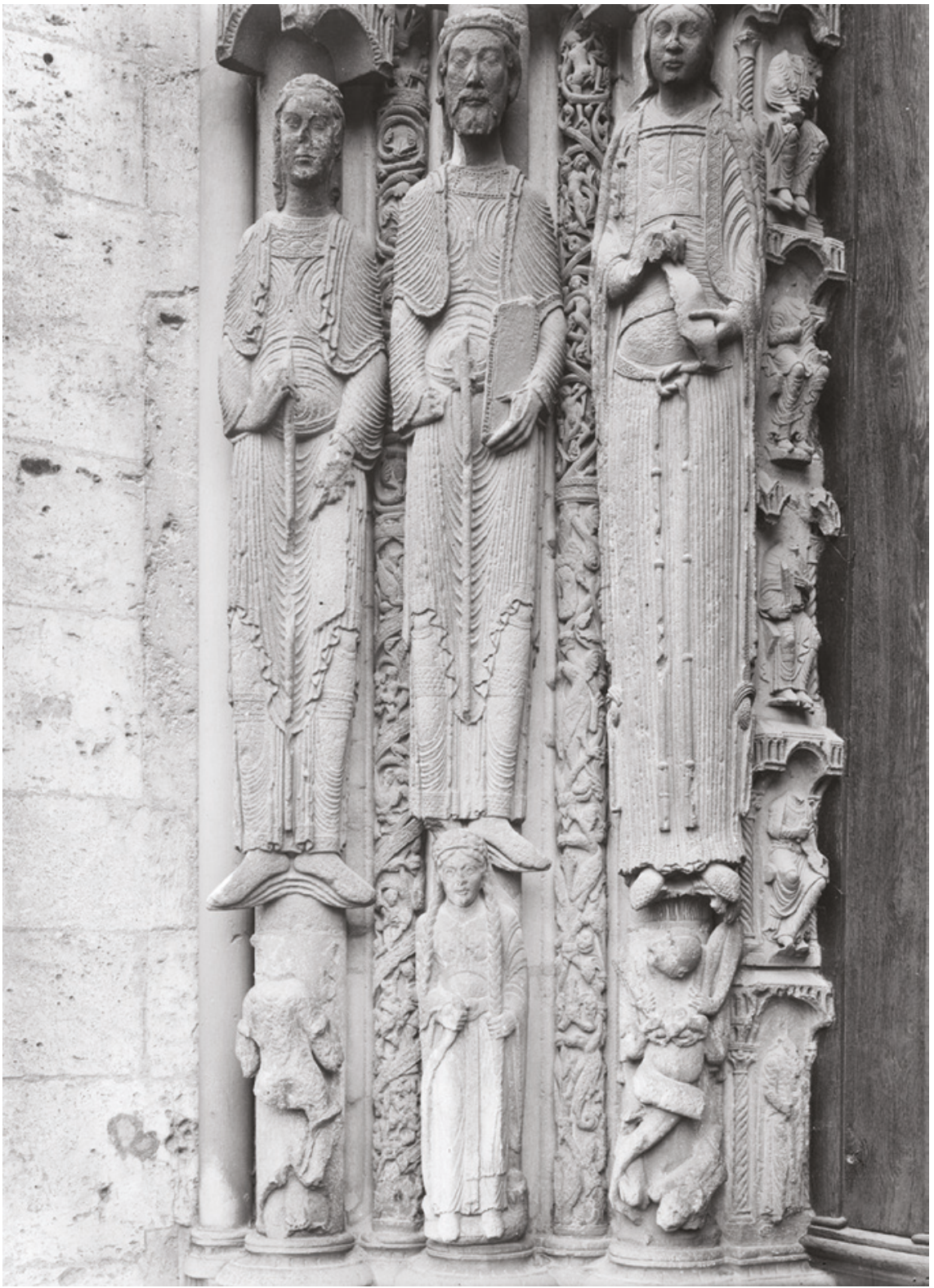

FIGURE 10.6 Chartres, Notre-Dame, Royal Portal, north gate, left jambs, two kings and a woman figures, c. 1145

(C) BILDARCHIV FOTO MARBURG 


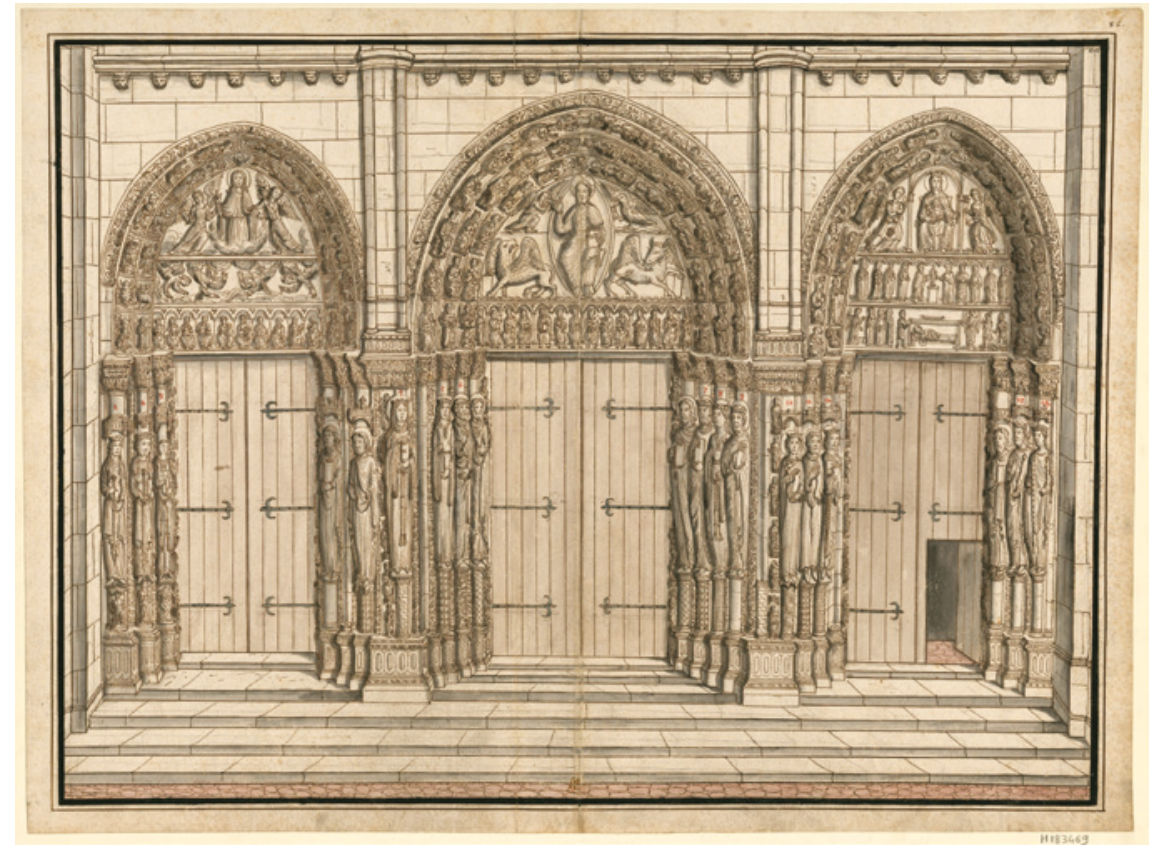

FIGU RE 10.7 Louis Boudan, dessin pour Roger de Gaignières, [Vue du Portail royal de la cathédrale de Chartres], 1696, Paris, BnF, département des Estampes et de la Photographie, Va $404 \mathrm{ft} 4$

(C): BNF 


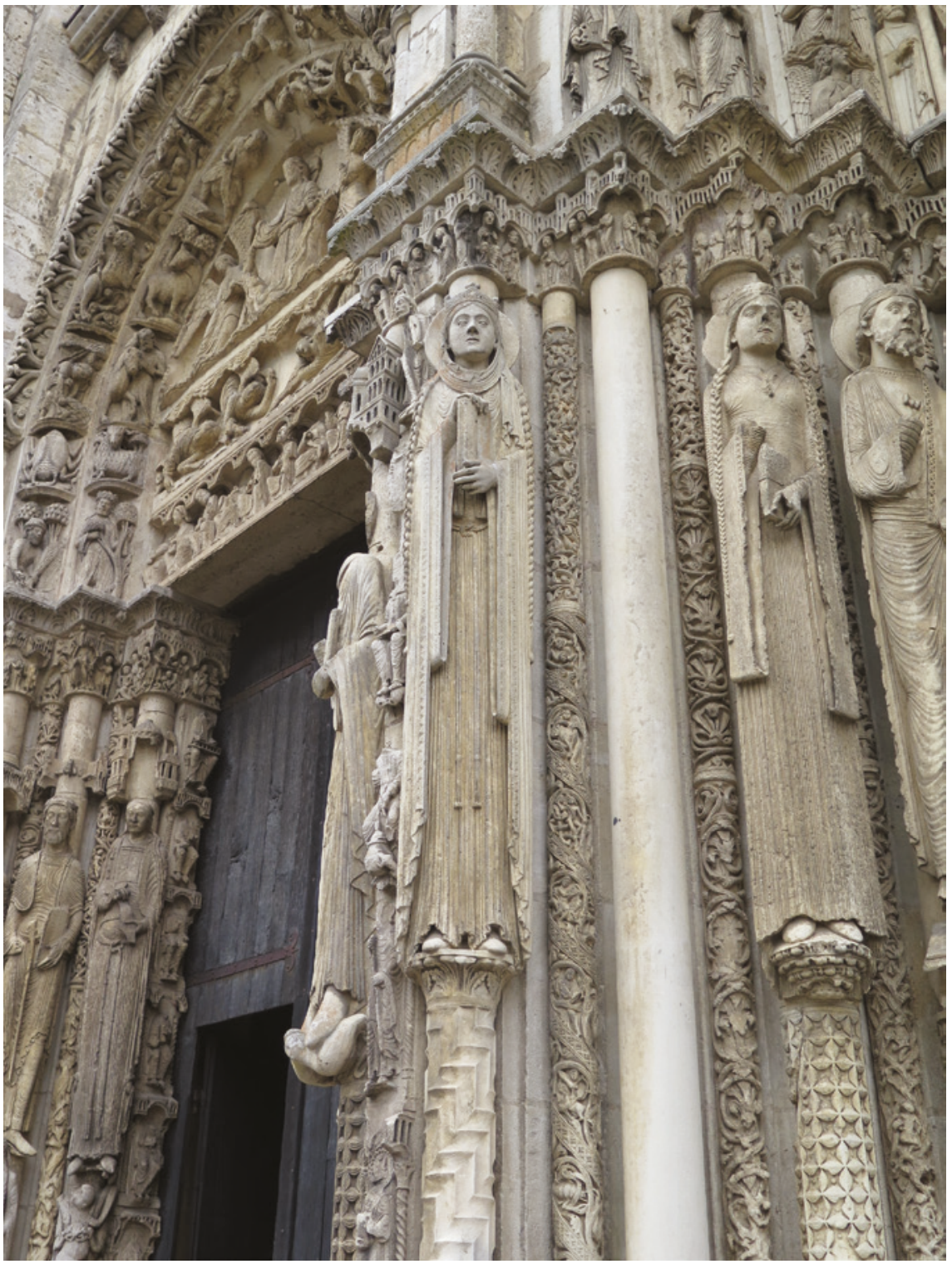

FI GURE 10.8 Chartres, Notre-Dame, Royal Portal, center gate, left jambs, two queens (?), c. 1145 (c): DAVE LÜTHI 


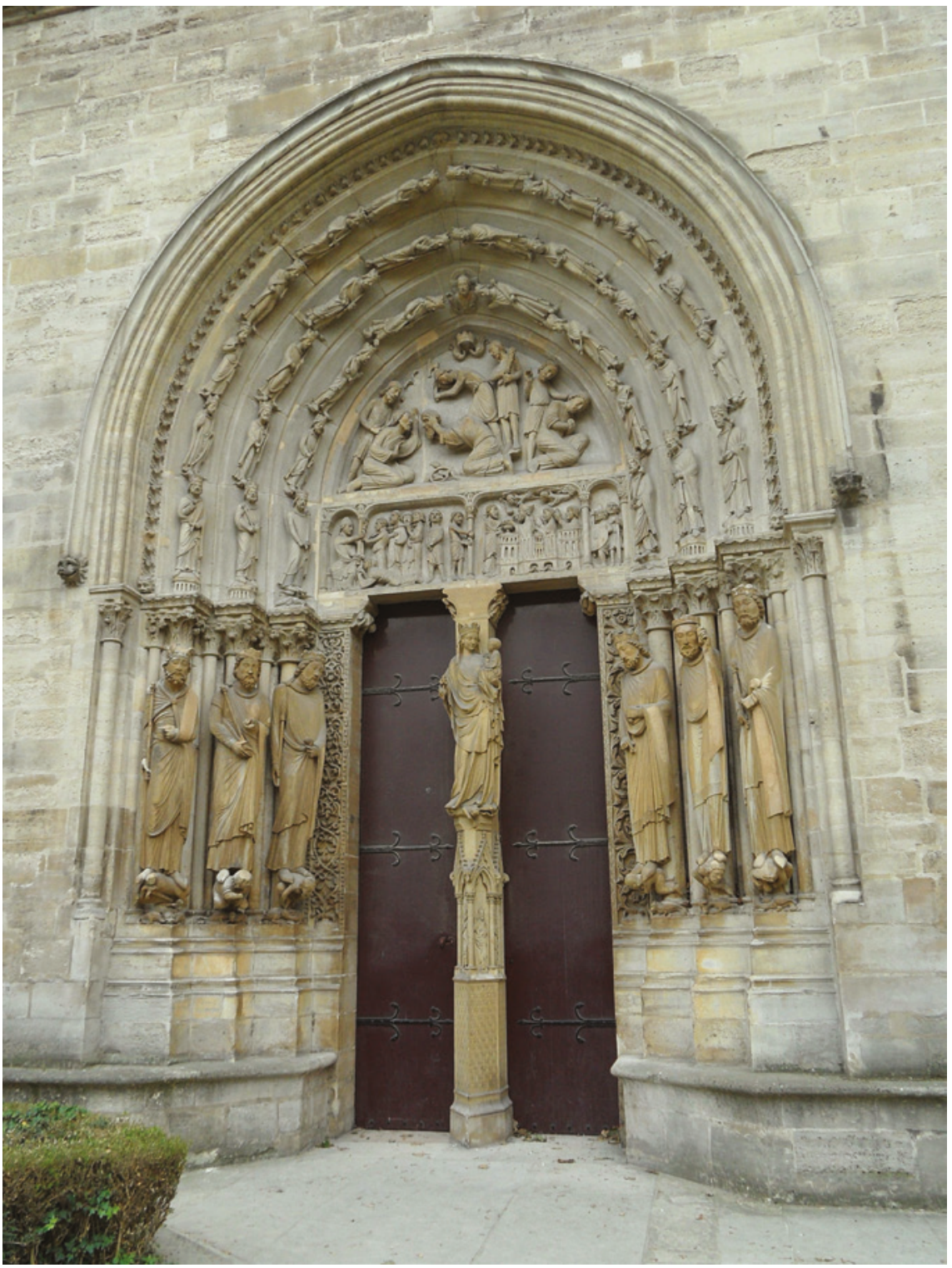

FIgURE 10.9 Saint-Denis, Abbey, transept, north arm, Porte des Valois, 115os

(C) MATTHIAS NONNENMACHER 


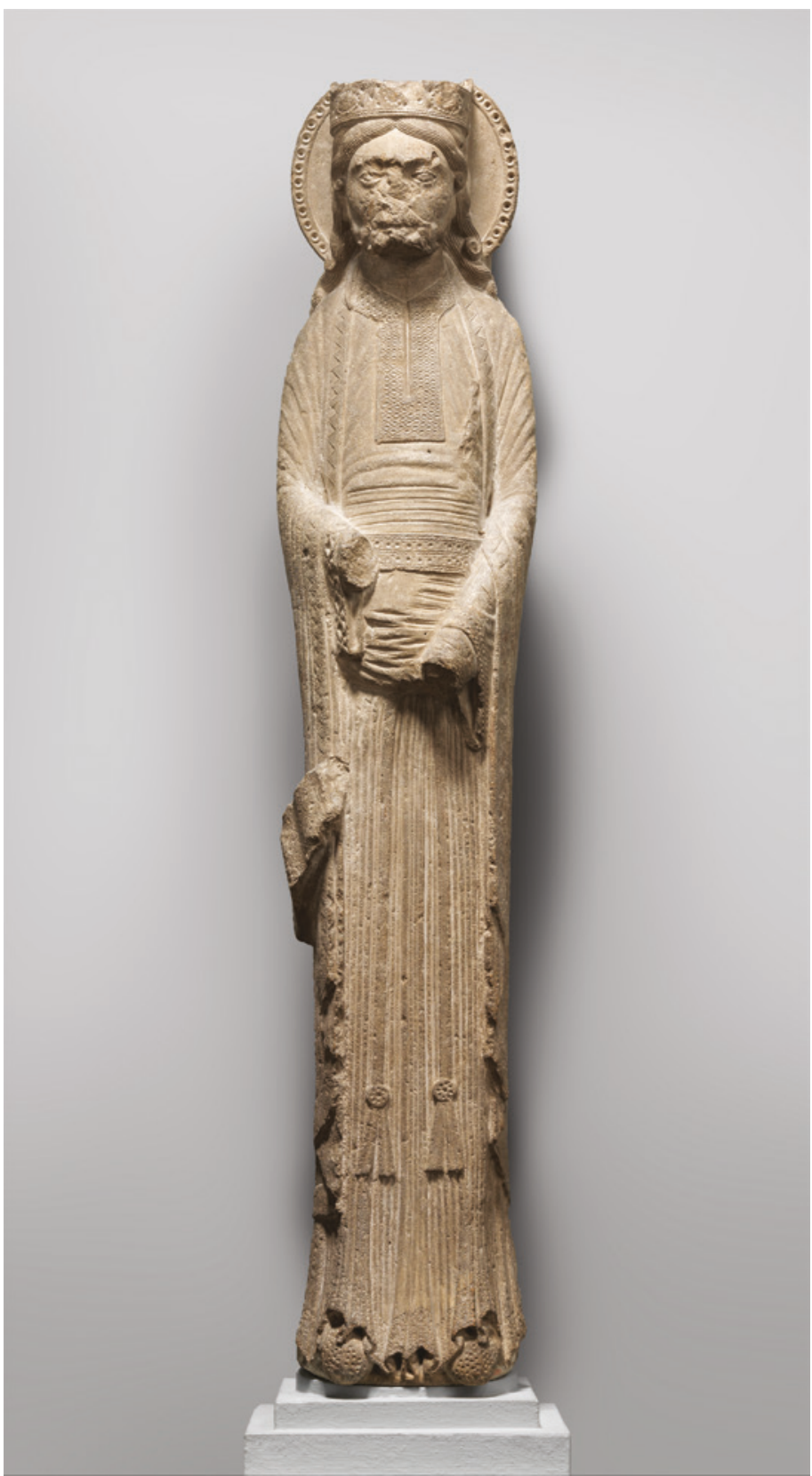

FIGURE 10.10 Saint-Denis, Abbey, cloister, column-figure, king of the Old Testament, c. 1145, New York, The Metropolitan Museum of Art, Pulitzer Bequest, inv. 20.157 (C)MET 


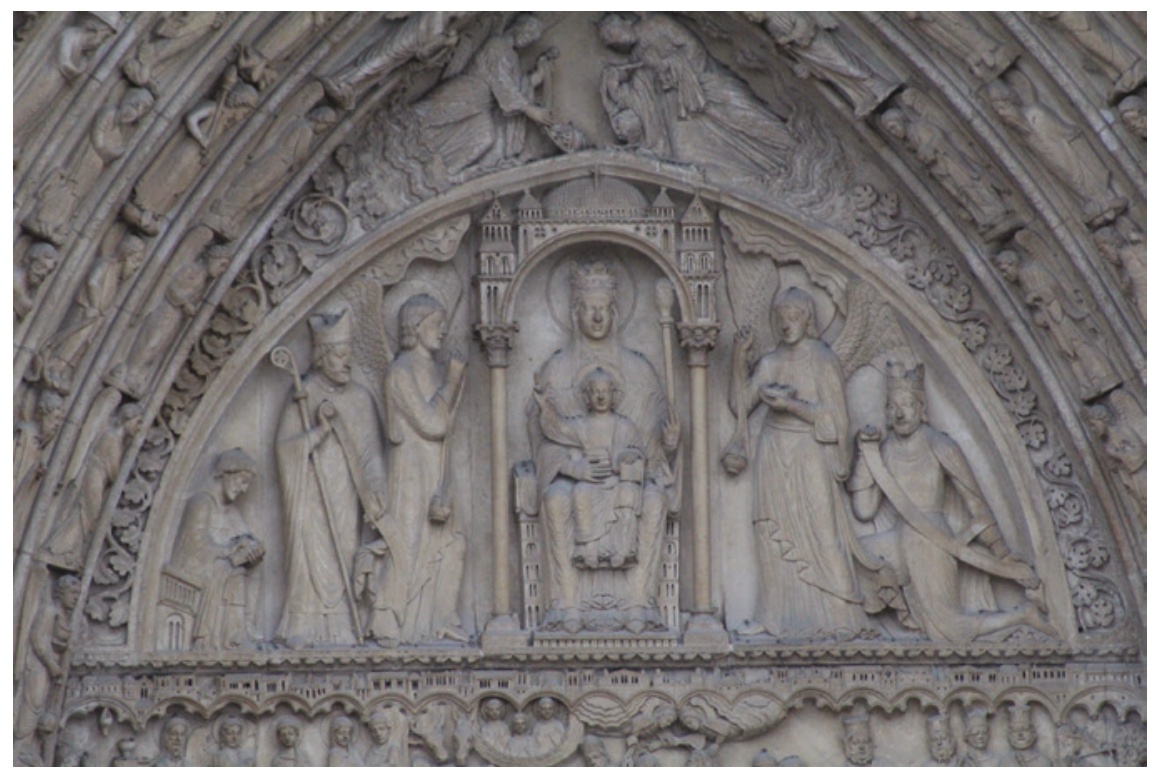

FIG URE 10.11 Paris, Notre-Dame, west façade, Portail Sainte-Anne, c. 1145 (C) CREATIVCOMMONS 


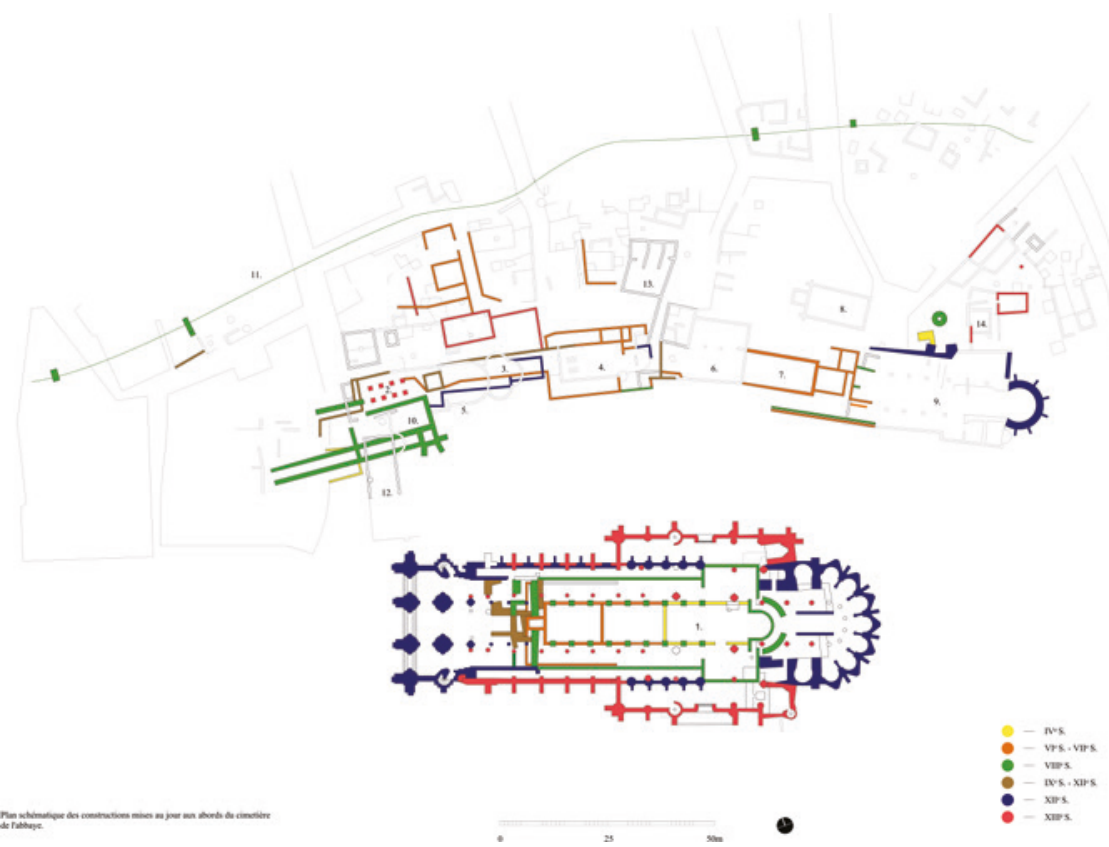

FIGURE 10.12 schematic plan of the buildings uncovered in the area around the abbey cemetery from Michaël Wyss (dir.), Atlas historique de Saint-Denis. Des origines au XVIIIe siècle, (Paris, 1996), coll. Documents d'archéologie française 59, p. 120 (C) SEBASTIAN BAUMANN 


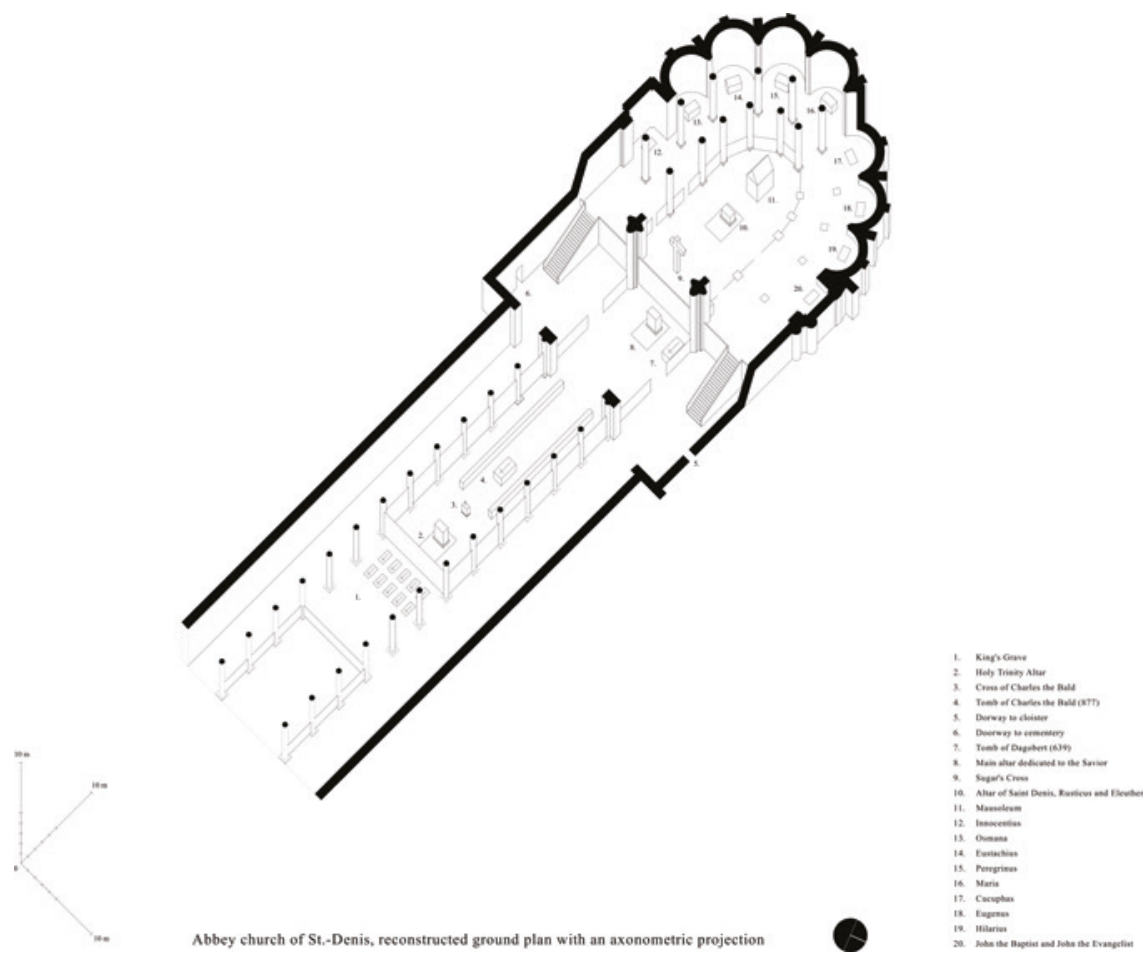

FIGURE 10.13 Plan of Saint-Denis during Suger abbatiat from Werner Jacobsen, "Liturgische Kollisionen im Kirchenraum: Sugers Neubau von Saint-Denis. Voraussetzungen und Folgen", in Art, Cérémonial et Liturgie au Moyen Âge, dir. Nicolas Bock, Peter Kurmann, Serena Romano and Jean-Michel Spieser, (Rome, 2002), p. 218

(C) SEBASTIAN BAUMANN 